\title{
Terrestrial Lidar Datasets of New Orleans, Louisiana, Levee Failures from Hurricane Katrina, August 29, 2005
}

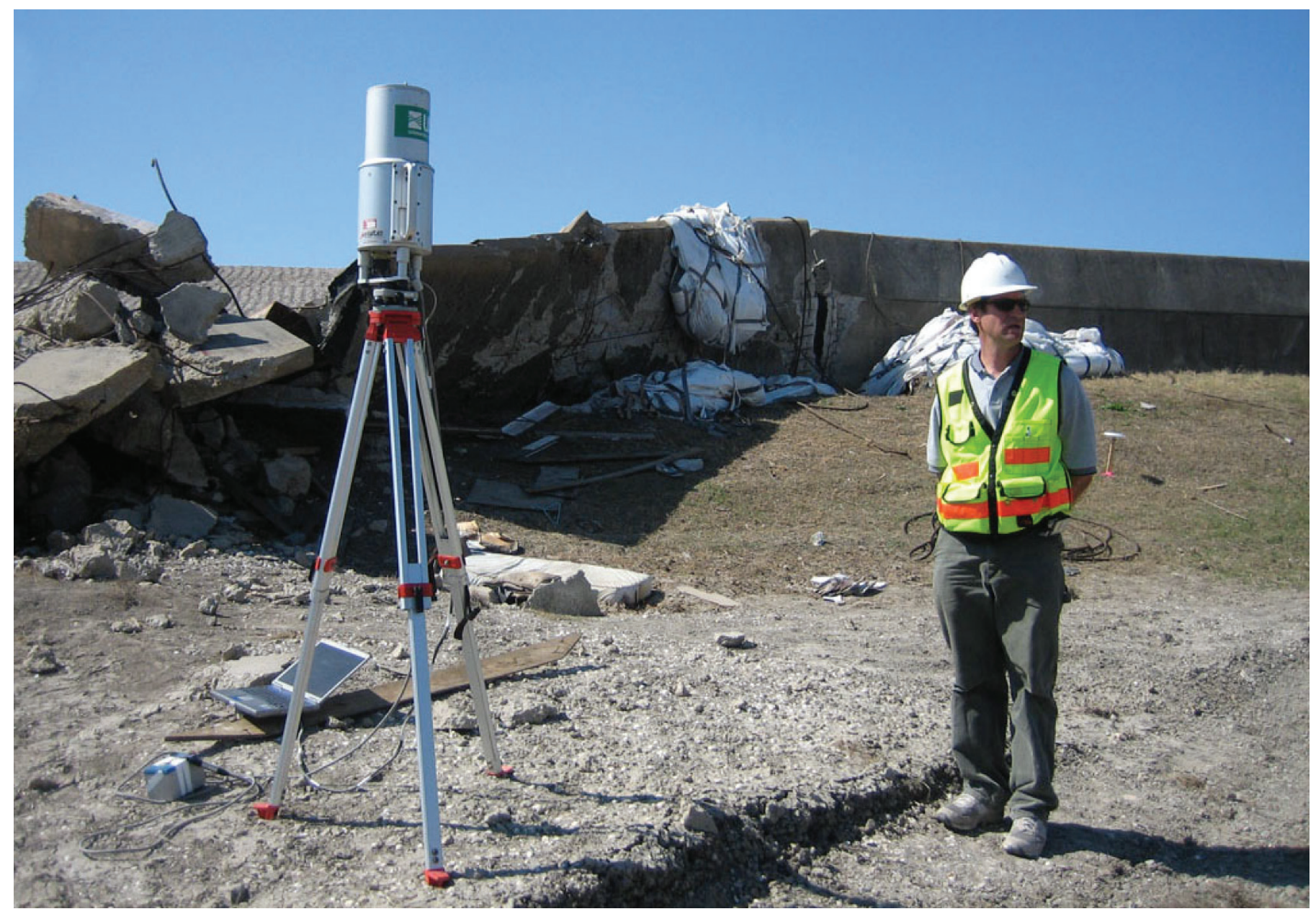

Data Series 470 
FRONT COVER- Terrestrial lidar data collection in front of the Inner Harbor Navigation Canal (IHNC) East Levee breach. 


\section{Terrestrial Lidar Datasets of New Orleans, Louisiana, Levee Failures from Hurricane Katrina, August 29, 2005}

By Brian D. Collins, Robert Kayen, Diane Minasian, and Thomas Reiss

Data Series 470

U.S. Department of the Interior

U.S. Geological Survey 


\section{U.S. Department of the Interior \\ KEN SALAZAR, Secretary \\ U.S. Geological Survey \\ Suzette M. Kimball, Acting Director}

\section{U.S. Geological Survey, Reston, Virginia: 2009}

This report and any updates to it are available online at:

http://pubs.usgs.gov/ds/470/

For more information on the USGS - the Federal source for science about the Earth, its natural and living resources, natural hazards, and the environment, visit http://www.usgs.gov or call 1-888-ASK-USGS

For an overview of USGS information products, including maps, imagery, and publications, visit http://www.usgs.gov/pubprod

To order this and other USGS information products, visit http://store.usgs.gov

Any use of trade, product, or firm names is for descriptive purposes only and does not imply endorsement by the U.S. Government.

Although this report is in the public domain, permission must be secured from the individual copyright owners to reproduce any copyrighted materials contained within this report.

Suggested citation:

Collins, B.D., Kayen, R., Minasian, D., and Reiss, T., 2009. Terrestrial lidar datasets of New Orleans, Louisiana, levee failures from Hurricane Katrina, August 29, 2005: U.S. Geological Survey Data Series 470, 24 p. 


\section{Contents}

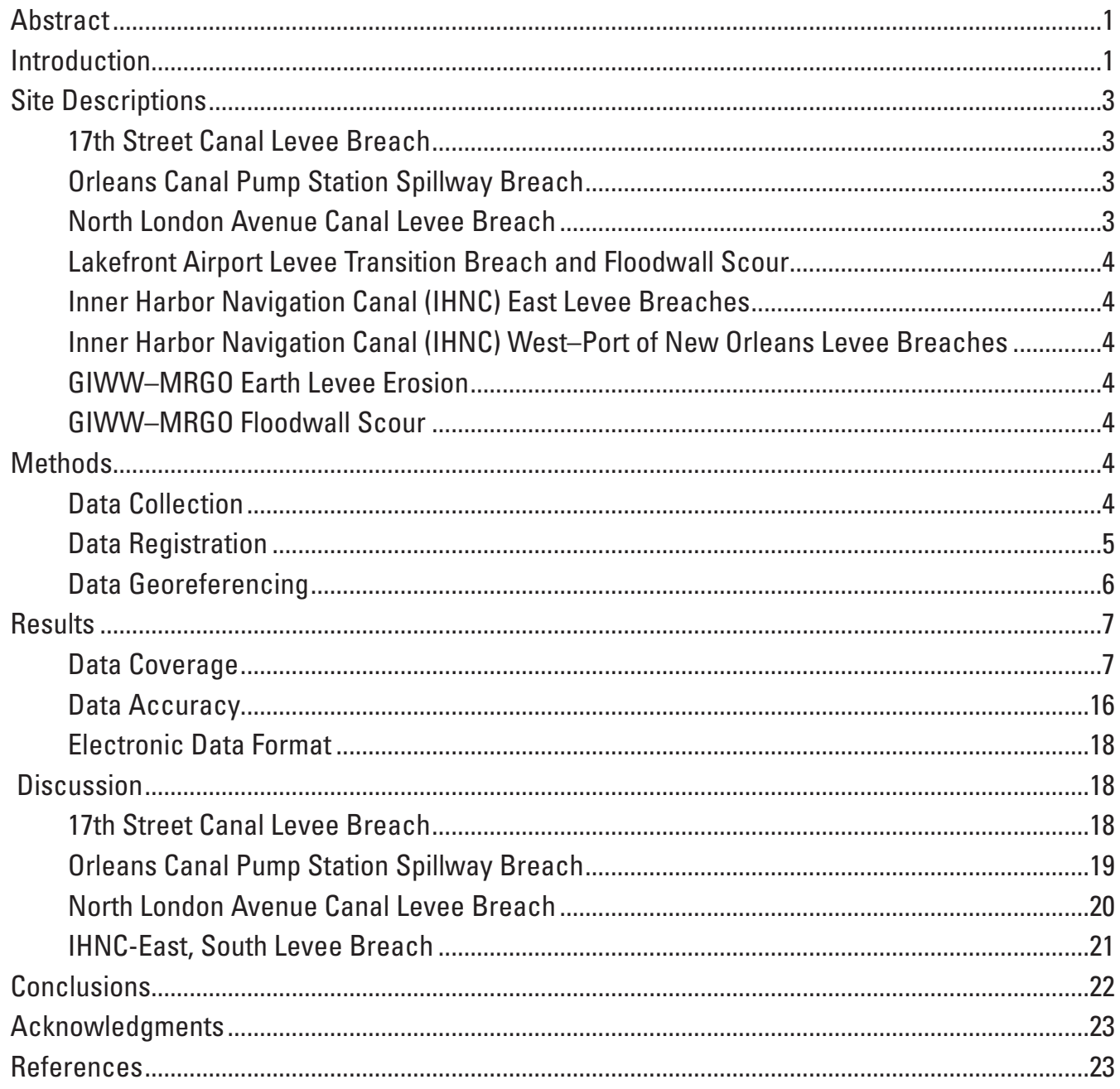

\section{Figures}

1. Levee breach damage in the Lower Ninth Ward of New Orleans along the Inner Harbor Navigational Canal (IHNC).

2. New Orleans, Louisiana, area map showing levee-failure sites documented with terrestrial lidar. .6

3. Tripod-mounted $(A)$ and vehicle-mounted $(B)$ terrestrial lidar data collection............................9

4. $A$, Lidar data collection at a single scan location (scan at the Inner Harbor Navigational Canal (IHNC) North Breach. B, Lidar image of same location ...............................10

5. Lidar image oblique view of multiple scans (scan locations 13-17) at the IHNC North Breach required to fill shadow zones.

6. Corners of buildings $(A)$ and gutters $(B)$ provide well-defined global positioning system (GPS) survey points for georeferencing the lidar point-cloud datasets.

7. Site $1-17$ th Street Canal levee breach 
8. Site 2-Orleans Canal pump station spillway breach .................................................................14

9. Site 3 -North London Avenue Canal levee breach ..............................................................15

10. Site 4-Lakefront Airport levee transition breach and floodwall scour .....................................16

11. Site 5-Inner Harbor Navigational Canal (IHNC)-East levee breaches ........................................17

12. Site 6-Inner Harbor Navigational Canal (IHNC)-West-Port of

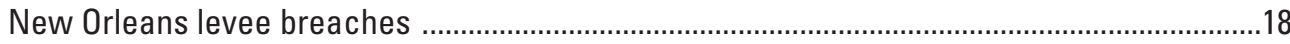

13. Site 7-Gulf Intracoastal Waterway-Mississippi River Gulf Outlet (GIWW-MRG0)

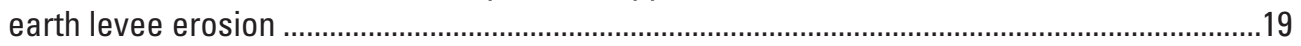

14. Site 8-Gulf Intracoastal Waterway-Mississippi River Gulf Outlet (GIWW-MRGO) floodwall scour .......................................................................................................................20

15. Image $(A)$ and high resolution terrestrial lidar data coverage image $(B)$ of displaced block stratigraphy from the 17th Street Canal levee breach. ...........................................................21

16. Example of data format for terrestrial lidar digital files included with this report.....................22

17. Overview oblique lidar image $(A)$ of the 17th Street Canal area in the vicinity of the breach and close-up view lidar image $(B)$ of the breach area showing key features ..........................23

18. Lidar image cross section of the 17th Street Canal breach looking northward..........................24

19. Lidar image of Orleans Canal pump station and floodwalls showing discrepancy between as-built elevations of spillway and adjacent floodwall..........................24

20. $A$, Lack of floodwall continuity along the northeast abutment of the Robert E. Lee Blvd bridge over the London Avenue Canal. $B$, Measurements from the lidar data provide exact elevations of each floodwall section relative to the vertical datum.

21. $A$, Leaning floodwall on the east side of the London Avenue Canal. $B$, Lidar image cross sections through three segments of the floodwall.

22. $A$, Scour trench at the south end of Inner Harbor Navigational Canal. $B$, Measurement of maximum scour-trench dimensions in the point cloud data near the south end of the south breach

\section{Tables}

1. Site description and locations...........................................................................................

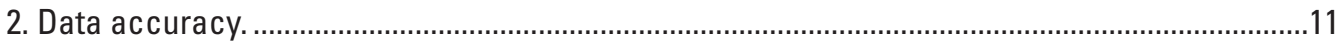

3. Terrestrial lidar data files of Hurricane Katrina levee failures in New Orleans..........................12 


\title{
Terrestrial Lidar Datasets of New Orleans, Louisiana, Levee Failures from Hurricane Katrina, August 29, 2005
}

\author{
By Brian D. Collins', Robert Kayen², Diane Minasian², Thomas Reiss²
}

\section{Abstract}

Hurricane Katrina made landfall with the northern Gulf Coast on August 29, 2005, as one of the strongest hurricanes on record. The storm damage incurred in Louisiana included a number of levee failures that led to the inundation of approximately 85 percent of the metropolitan New Orleans area. Whereas extreme levels of storm damage were expected from such an event, the catastrophic failure of the New Orleans levees prompted a quick mobilization of engineering experts to assess why and how particular levees failed. As part of this mobilization, civil engineering members of the United States Geological Survey (USGS) performed terrestrial lidar topographic surveys at major levee failures in the New Orleans area. The focus of the terrestrial lidar effort was to obtain precise measurements of the ground surface to map soil displacements at each levee site, the nonuniformity of levee height freeboard, depth of erosion where scour occurred, and distress in structures at incipient failure. In total, we investigated eight sites in the New Orleans region, including both earth and concrete floodwall levee breaks. The datasets extend from the 17th Street Canal in the Orleans East Bank area to the intersection of the Gulf Intracoastal Waterway (GIWW) with the Mississippi River Gulf Outlet (MRGO) in the New Orleans East area. The lidar scan data consists of electronic files containing millions of surveyed points. These points characterize the topography of each levee's postfailure or incipient condition and are available for download through online hyperlinks. The data serve as a permanent archive of the catastrophic damage of Hurricane Katrina on the levee systems of New Orleans. Complete details of the data collection, processing, and georeferencing methodologies are provided in this report to assist in the visualization and analysis of the data by future users.

\section{Introduction}

Hurricane Katrina made landfall with the northern Gulf Coast on August 29, 2005, as one of the strongest hurricanes on record. Wind and storm-surge damage affected hundreds of kilometers of coastline, including large swaths of Mississippi and eastern Louisiana. The damage incurred in Louisiana included a number of levee failures that led to the inundation of approximately 85 percent of the metropolitan New Orleans area. The levee failures attracted considerable attention, aside from the existing hurricane damage, because of the loss of life and property (fig. 1) and the necessary evacuation of the entire city's population. Whereas extreme levels of storm damage were expected from such an event, the catastrophic failure of the New Orleans levees, themselves part of an engineered system, prompted a quick mobilization of engineering experts to assess why and how particular levees failed.

As part of this mobilization, civil engineering members of the United States Geological Survey (USGS) responded to the crisis through joint efforts with the Independent Levee Investigation Team (ILIT), based out of the University of California, Berkeley. The ILIT consisted of levee design and analysis experts acting as independent volunteers, with travel and logistical financial support from the National Science Foundation (NSF). The ILIT rapidly produced a preliminary report of observations, which was submitted to the U.S. Senate in

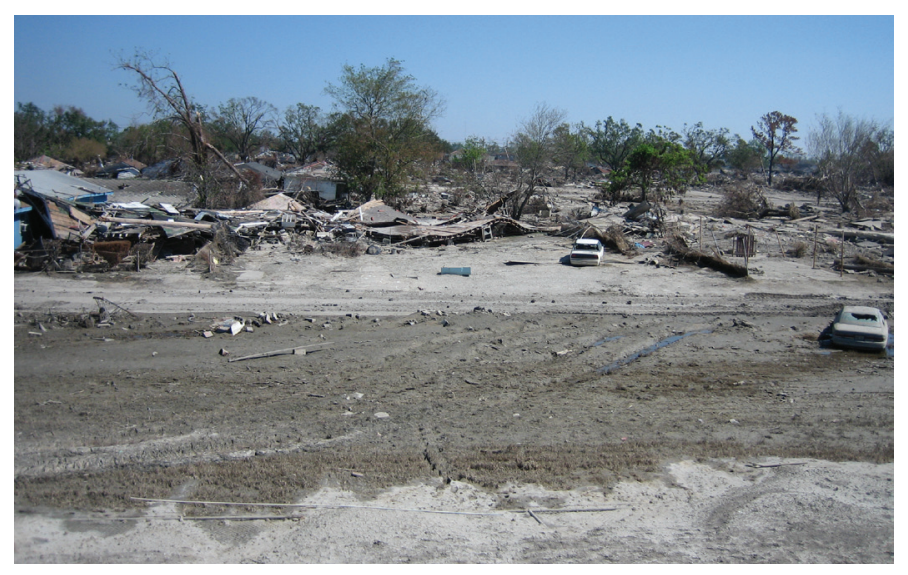

Figure 1. Levee breach damage in the Lower Ninth Ward of New Orleans along the Inner Harbor Navigational Canal (IHNC).

${ }^{1}$ U.S. Geological Survey, Earth Surface Processes Team, Menlo Park, California.

${ }^{2}$ U.S. Geological Survey, Coastal and Marine Geology Team, Menlo Park, California. 
November, 2005 (ILIT, 2005), followed by a final report of analyses on the levee failure mechanisms (ILIT, 2006) some 8 months later. Scientific papers were subsequently published outlining the conclusions of the investigation (Seed and others, 2008a, 2008b, 2008c, 2008d). The USGS members of the ILIT, experienced in the rapid collection of perishable deformation data following landslide and earthquake events, performed terrestrial lidar topographic surveys at major levee failures in the New Orleans area. Preservation of information regarding the magnitude and geometry of structural and geotechnical deformations was paramount for the analysis of levee failure modes-important clues can often be extracted from the before and after comparison of ground and structural topography. The focus of the terrestrial lidar effort was to obtain precise measurements of the ground surface to map soil displacements at each levee site, the nonuniformity of levee height freeboard, depth of erosion where scour occurred, and distress in structures at incipient failure.
Terrestrial lidar (also called three-dimensional laser scanning or ground-based lidar) is a remote sensing survey method suitably designed for rapid reconnaissance purposes. With this method, millions of topographic survey points can be collected in a matter of minutes using a ground-based platform. Survey points are typically collected at centimeter-scale accuracy at ranges of as much as hundreds of meters. In the near range, survey point density can exceed 50 points per square meter. The technique has been successfully applied to a number of quantitative geomorphologic studies (for example, Bellian and others, 2005; Collins and Sitar, 2002, 2008; Doneus and Neubauer, 2005; Labourdette and Jones, 2007; Nagihara and others, 2004; Wawrzyniec and others, 2007), including natural-hazard reconnaissance efforts ranging from landslides (Collins and others, 2007) to earthquake events (Kayen and others, 2006). The benefits of a terrestrial lidar investigation in postevent reconnaissance efforts are (1) the rapid and remote measurement of detailed failure morphologies of damaged

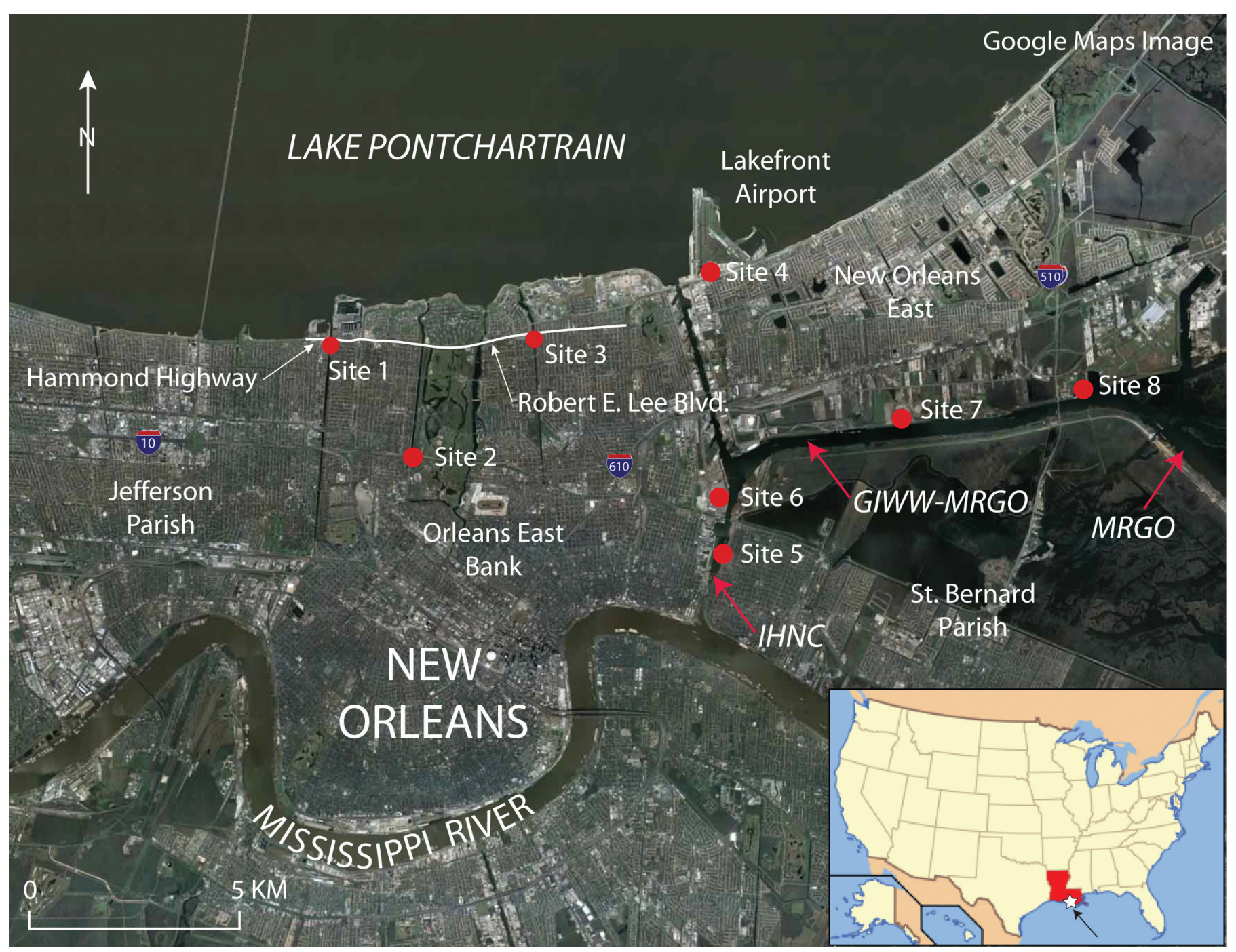

Figure 2. New Orleans, Louisiana, area map showing levee-failure sites documented with terrestrial lidar. 
ground and structures; (2) the ultra-high resolution of surfaces, deformation patterns, and failure morphologies on a computer screen in orientations and at scales not previously possible; and (3) the ability to permanently archive three-dimensional terrain models of damage useful for the engineering community to ground-truth and evaluate analytical models of deformation.

In total, we investigated eight sites in the New Orleans region, including both earth and concrete floodwall levee breaks. The datasets extend from the 17th Street Canal in the Orleans East Bank area to the intersection of the Gulf Intracoastal Waterway (GIWW) with the Mississippi River Gulf Outlet (MRGO) in the New Orleans East area (fig. 2). These sites, along with their approximate geodetic locations, are listed in table 1 . The laser scanning effort was conducted over a 5-day period from October 9 to 13, 2005. An additional day of laser data collection was performed on March 15, 2006, at the Orleans Canal Pump Station during a followup survey effort conducted from March 13 to 17, 2006. During this second trip, GPS-acquired, geodetic-quality survey points were collected to georeference some of the previously obtained laser scans.

This report outlines the methods, data, and general results obtained from the terrestrial lidar and GPS surveying efforts performed on the Hurricane Katrina levee failures. Although some data have been presented in previous reports (for example, see ILIT, 2006), the data provided in this report have been subject to additional review, processing, and analysis. Thus, minor discrepancies may exist between the data presented here and reports presented previously. The lidar scan data consists of electronic files containing millions of surveyed points. These points characterize the topography of each levee's postfailure or incipient condition and are available for download through online hyperlinks. The data serve as a permanent archive of the

Table 1. Site description and locations.

[IHNC, Inner Harbor Navigation Canal (Industrial Canal); GIWW, Gulf Intracoastal Waterway; MRGO, Mississippi River Gulf Outlet]

\begin{tabular}{|c|c|c|c|}
\hline $\begin{array}{l}\text { Lidar Site } \\
\text { Number }\end{array}$ & Site Description & $\begin{array}{l}\text { Latitude } \\
\text { (WGS84) }\end{array}$ & $\begin{array}{l}\text { Longitude } \\
\text { (WGS84) }\end{array}$ \\
\hline 1 & 17th Street Canal Levee Breach & $\mathrm{N} 30.0172^{\circ}$ & W90.1214 \\
\hline 2 & $\begin{array}{l}\text { Orleans Canal Pump Station } \\
\text { Spillway Breach }\end{array}$ & $\mathrm{N} 29.9948^{\circ}$ & W90.1007 \\
\hline 3 & $\begin{array}{l}\text { North London Avenue Canal } \\
\text { Levee Breach }\end{array}$ & $\mathrm{N} 30.0206^{\circ}$ & W90.0708 \\
\hline 4 & $\begin{array}{l}\text { Lakefront Airport Levee Transi- } \\
\text { tion Breach and Floodwall } \\
\text { Scour }\end{array}$ & $\mathrm{N} 30.0337^{\circ}$ & W90.0262 \\
\hline 5 & IHNC-East Levee Breaches & $\mathrm{N} 29.9724^{\circ}$ & W90.0225 \\
\hline 6 & $\begin{array}{l}\text { IHNC-West - Port of New } \\
\text { Orleans Levee Breaches }\end{array}$ & $\mathrm{N} 29.9861^{\circ}$ & $\mathrm{W} 90.0272^{\circ}$ \\
\hline 7 & $\begin{array}{l}\text { GIWW-MRGO Earth Levee } \\
\text { Erosion }\end{array}$ & $\mathrm{N} 30.0020^{\circ}$ & W89.9750 \\
\hline 8 & GIWW-MRGO Floodwall Scour & $\mathrm{N} 30.0090^{\circ}$ & W89.9317 \\
\hline
\end{tabular}

catastrophic damage of Hurricane Katrina on the levee systems of New Orleans. Complete details of the data collection, processing, and georeferencing methodologies are provided in this report to assist in the visualization and analysis of the data by future users.

\section{Site Descriptions}

As a background to the presentation of the electronic datasets, we provide the following brief description and relevant information about events that occurred at each site during Hurricane Katrina. More in-depth descriptions can be found in the ILIT (2006) report.

\section{7th Street Canal Levee Breach}

The 17th Street Canal is located in the Orleans East Bank area of New Orleans along one of several linear drainage canals connected to Lake Pontchartrain to the north (fig. 2, site 1). The levee breach occurred along 142 meters of the east bank of the canal just south of the Hammond Highway bridge. Several homes in the immediate vicinity of the breach were destroyed by water pushing them from their foundations. An incipient failure of the canal's west bank also occurred directly opposite the breach, but that bank did not fail, presumably because the east bank failed first (Seed and others, 2008d). If this section had failed, a much larger area of New Orleans, extending westward into Jefferson Parish, would have flooded.

\section{Orleans Canal Pump Station Spillway Breach}

The Orleans Canal is located $2 \mathrm{~km}$ east of the 17th Street Canal, just north of Interstate Highway 610 and drains northward towards Lake Pontchartrain (fig. 2, site 2). Although a levee failure did not technically occur along this canal, an engineering failure did occur near the pump station located at the southern end that was responsible for much of the flooding of the downtown area. Here, a purposefully designed spillway, some 1.3 meters below the elevation of the surrounding floodwalls on either side of the canal, allowed the storm surge from the hurricane to flood the area directly. The spillway was designed to prevent the collapse of the adjacent pump station, constructed in the early 1900's, by rising floodwaters in the canal. Although several other design alternatives were available, none were constructed.

\section{North London Avenue Canal Levee Breach}

The London Avenue Canal is located $2.5 \mathrm{~km}$ to the east of the Orleans Canal (fig. 2). It too is another one of several drainage canals of the Orleans East Bank basin that connect to Lake Pontchartrain. Two levee breaches occurred along this canal: one near the north end of the canal and one located approximately $1.5 \mathrm{~km}$ south. Our data collection efforts only 
focused on the northern breach (fig. 2, site 3). The northern breach occurred immediately south of the Robert E. Lee Boulevard bridge crossing, on the west side of the canal. An incipient failure also occurred on the east side, directly across from the west side breach.

\section{Lakefront Airport Levee Transition Breach and Floodwall Scour}

Lakefront Airport is located in the northwest corner of the New Orleans East basin, immediately south of Lake Pontchartrain and east of the Inner Harbor Navigation Canal (IHNC) (fig. 2, site 4). Although a 3-m-tall concrete floodwall performed well over most of its length near the airport, a breach occurred at the intersection of the concrete floodwall and the adjoining railway-line earth embankment. The resultant flooding of a large section of the New Orleans East basin highlights an important lesson learned during the aftermath of the hurricane - that transitions between both physical structures and neighboring flood-protection authorities must be carefully designed, maintained, and administered.

\section{Inner Harbor Navigation Canal (IHNC) East Levee Breaches}

Two breaches along the east side of the IHNC (also known locally as the Industrial Canal; fig. 2, site 5) led to catastrophic destruction of a majority of the Lower Ninth Ward of New Orleans, destroying many homes outright and flooding the remainder. The approximately $55-\mathrm{m}$-long north breach was located about $680 \mathrm{~m}$ northward of the 250-m-long south breach. Some debate still exists as to whether the larger southern breach occurred because of poor geotechnical design of the embankment or scour-trench-induced failure of the levee floodwalls (Seed and others, 2008d).

\section{Inner Harbor Navigation Canal (IHNC) West- Port of New Orleans Levee Breaches}

On the west side of the IHNC, at the Port of New Orleans (fig. 2, site 6), we observed breaches of concrete floodwall sections and an earth embankment composed of highly erodible fill material. The site is aligned directly across from the terminus of the Gulf Intracoastal Waterway-Mississippi River Gulf Outlet canal (GIWW-MRGO) where it intersects the IHNC (fig. 2). As such, it may have been subjected to large hydrostatic and hydrodynamic stresses when the storm surge associated with the hurricane arrived. Analyses by Seed and others (2008d) show that the floodwall sections failed because of floodwater overtopping, scour trench formation, and subsequent wall toppling. This mode of failure can be prevented through the use of nonerosive "splash pads" on the protected side of the wall to prevent scour trench formation or by improved design of the floodwalls themselves. The breaches in this location did not scour to below sea level, thus they were responsible for only a portion of the flooding of New Orleans that occurred during the hurricane when the storm surge was greatest.

\section{GIWW-MRGO Earth Levee Erosion}

The Gulf Intracoastal Waterway-Mississippi River Gulf Outlet canal forms the south border of the New Orleans East basin (fig. 2) and provides a navigable link from the city of New Orleans (by way of the IHNC) directly to the Gulf of Mexico. In addition to exacerbating storm-surge-induced flooding in the Saint Bernard Parish basin (located south of the GIWW-MRGO, west of the MRGO, and east of the IHNC and Mississippi River), several levee breaches and near-failures occurred along both sides of this waterway (Seed and others, 2008a). We investigated an area of severe scour erosion on the north side of the GIWW-MRGO, located about halfway between the IHNC and the GIWW-MRGO split (fig. 2, site 7). The data show areas where levee overtopping formed deep $(>0.5 \mathrm{~m})$ scour marks on the protected side of the levee. In 2008, the MRGO portion of this canal was officially deauthorized by the Army Corps of Engineers and the southern end of the canal was closed by a rock structure in 2009 .

\section{GIWW-MRGO Floodwall Scour}

Further to the east (fig. 2, site 8), on the north side of the GIWW-MRGO and immediately to the west of the intersection of the GIWW and the MRGO waterways, a 2- to 2.5-m-tall (as measured on the protected side of the wall) concrete floodwall was overtopped, resulting in scour trenches forming behind the wall (that is, on the protected side). Scour-trench depths were on the order of $1.2 \mathrm{~m}$, whereas trench width approached the height of the wall in places. This area is located adjacent to the Entergy Michoud Plant, a provider of electrical power to the New Orleans region. The plant was closed for 8 months following the hurricane because of storm and flood damage. Storm surge at this location was extremely high because of its close proximity to the path of the hurricane.

\section{Methods}

\section{Data Collection}

Terrestrial lidar data collection consists of reflecting highfrequency laser pulses off the surface of objects to build a point file of three-dimensional (3-D) coordinates. The time of travel at a known velocity, (that is, the speed of light) for a single laser-pulse return from an object is measured along a known trajectory (azimuth and elevation angle) such that a relative position from the instrument is computed. Most laser scanners operate using some combination of precisely aligned rotating polygonal mirrors and extremely small-stepping motors to 

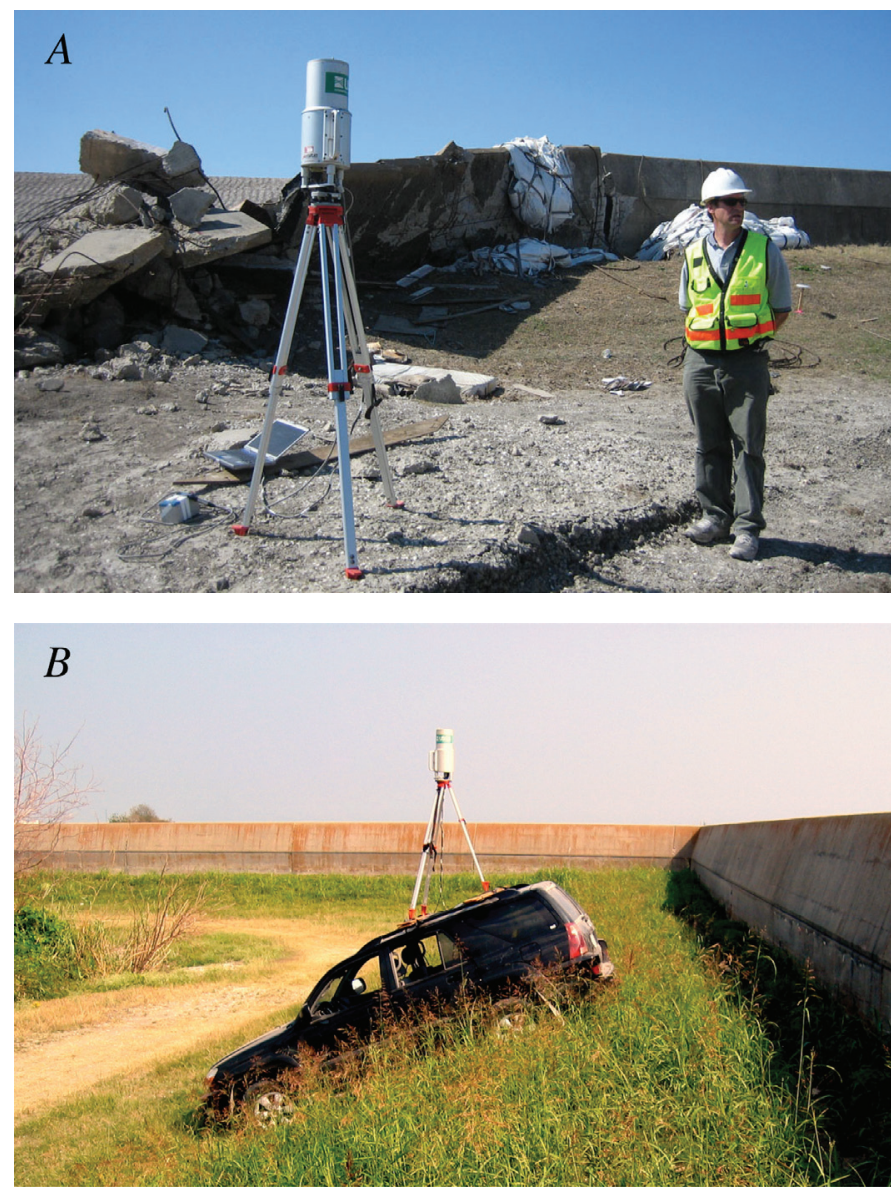

Figure 3. Tripod-mounted $(A)$ and vehicle-mounted $(B)$ terrestrial lidar data collection.

guide the laser paths over the area of interest. This technology, specifically developed for rapid topographic surveys, allows data to be collected at rates of thousands of points per second, generating a "point cloud" of 3-D coordinates that describes the topography of the area. Some laser scanners also collect visual data on points located both within and outside of the laser range through either integrated color sensors or digital cameras. This can provide an indication of point intensity and color for use in feature identification within a point cloud.

In this study, a Class 1 (eye-safe under normal operating conditions), near infrared (900 nm), pulsed laser diode, Riegl Z210 scanner (Riegl, 2008), with integrated color sensor, was utilized as a tripod-mounted laser scanning instrument (fig. $3 A$ ). In some cases, the instrument was elevated on a fixed platform (for example, the vehicle rooftop as shown in fig. $3 B$ ) to improve and extend the field of view and to increase the efficient transport of the instrument between individual scan set-up locations (herein referred to as "scans" or "scan locations"). At each scan location, we collected approximately 2.3 million data points in 5 minutes (scan rate of 8,000 points/ second) on seven channels (X coordinate, $\mathrm{Y}$ coordinate, $\mathrm{Z}$ coordinate, red color, green color, blue color, and reflective intensity). The color-channel data vary according to the lighting conditions during each particular scan. On a few occasions during the team's reconnaissance mission (fewer than 10 scans), schedules necessitated night-time data collection such that real-color scans could not be collected. This only affected the color imagery of the data, not the positional accuracy or resolution of the point files.

Scanning was performed at an azimuthal range of $336^{\circ}$ and an elevation range of positive $40^{\circ}$ to negative $40^{\circ}$, as measured from a horizontal plane, from each scan location. The distance range for natural targets from the Riegl Z210 instrument is between 2 and 350 meters. At these distances the point-measurement accuracy is $2.5 \mathrm{~cm}$, with a precision nearly 1,000 times greater. However, given the propensity for a laser beam to diverge at distance, the laser spot size at long range is larger than the center-point accuracy. For example, the Riegl Z210's beam divergence of $0.172^{\circ}$ results in a spot size of approximately $30 \mathrm{~cm}$ at $100-\mathrm{m}$ distance. Thus, point accuracy should be measured as a factor of both the spot size and center-point location. Point density is determined by angular step width, range, and target orientation. In New Orleans, we used an angular step width of $0.108^{\circ}$, resulting in near-field $(20 \mathrm{~m})$ point separation of approximately $4 \mathrm{~cm}$ and far-field (200 m) separation of approximately $40 \mathrm{~cm}$ for a surface target that is orthogonal to the instrument.

We collected multiple scans throughout each site to fill in areas not directly in the line of sight of any one laser setup (that is, shadow zones) and to expand the range and density of the point data. For example, at the south breach of the Inner Harbor Navigational Canal (fig. 4A) shadows were cast by near-field objects, like the deformed floodwall, over the scour trench and terrain behind it (fig. 4B). By adding additional scan locations on both sides of the floodwall, these shadows were removed (fig. 5) and the data density significantly increased. Each site required between 7 and 29 individual scanner set-ups to cover the entire feature and surrounding area and to minimize the number of shadow areas. Metadata from this field effort are available at http://walrus.wr.usgs.gov/ infobank/n/no105la/html/n-o1-05-la.meta.html.

\section{Data Registration}

Following data collection, we applied a suite of processing steps to align the scans in their proper orientation. This process, termed data registration, was performed through a best-fit iteration of each pair of neighboring point clouds using I-SiTE Studio software (I-SiTE, 2008), a software program specifically designed to handle terrestrial laser data. The bestfit algorithm is executed by aligning overlapping areas from adjacent point clouds with sufficiently dense points to find singular solutions to common, yet somewhat complex features. The data registration process can be executed with additional precision if the coordinates of each scan origin or a set of visible reflectors within each point cloud is known. However, given the rapid reconnaissance method used in this study, and with the exception of site 11 (the Orleans Canal Pump Station 

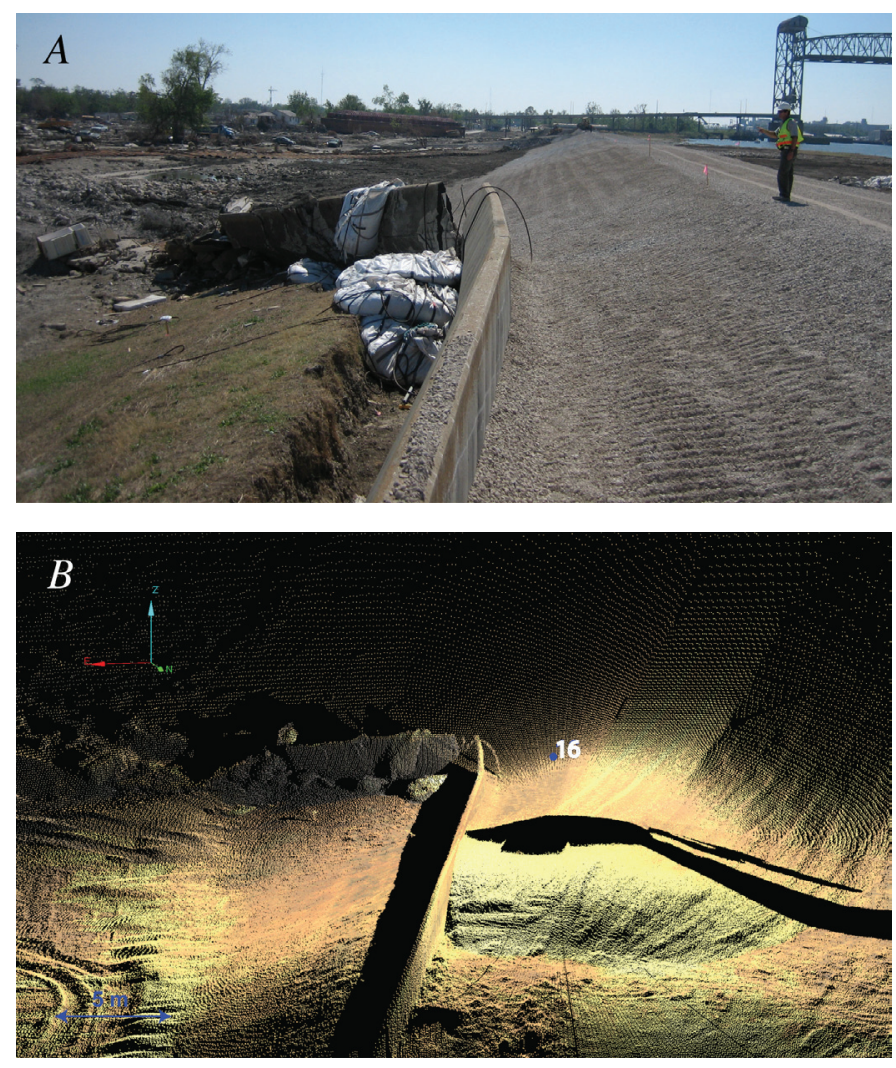

Figure 4. A, Lidar data collection at a single scan location (scan location 16) at the Inner Harbor Navigational Canal (IHNC) North Breach, showing how shadow zones are created from objects. $B$, Lidar image of same location. The scour-trench area immediately behind the wall and location of laser scanner (black areas) are not captured in the lidar data from this location.

Spillway, where data was collected in a later survey effort), this additional surveying practice was not performed. Instead, each dataset was collected and processed using a local coordinate system, centered on the origin of the first scan collected at each site. This provided a basis for understanding each site's morphology and for making relative measurements within a single site - sufficient for obtaining the data needed for the initial assessment of each of the levee breaches.

\section{Data Georeferencing}

To make absolute measurements in terms of other georeferenced datasets, including elevation measurements relative to a terrestrial datum, we performed a GPS control-point survey in March 2007, several months after the initial reconnaissance. The goal of this effort was to collect high-accuracy survey data on local control points identified within the point clouds as a means of georeferencing the datasets. Because of time and logistical constraints, we collected survey data for only five of the data sets (sites 1, 2, 3, 4, and 5). Metadata from the GPS survey effort are available at http://walrus.wr.usgs.gov/ infobank/n/no106la/html/n-o1-06-la.meta.html. The remaining three datasets (sites 6, 7, and 8) were georeferenced by a bestfit approximation using points obtained from Google Earth imagery and visible in the point cloud data. The accuracy is therefore much lower for these sites (table 2).

For the GPS surveys, we collected high-accuracy survey data on cultural features clearly visible in the scan sets (such as house roof corners, fence posts, concrete foundation corners; fig. 6). We used four dual-frequency GPS receivers (Ashtech Z-Xtreme, Model \#800889-C): two acting as static base receivers and two performing kinematic (rover) lidar control-point surveys. All receivers operated simultaneously to obtain the desired geodetic-quality registration points. Because many of the existing control points in the New Orleans area had been subject to long-term subsidence (Shinkle and Dokka, 2004), the static GPS receivers were positioned only over survey control points that had been accurately resurveyed following the hurricane by researchers at the Louisiana State University's Center for GeoInformatics in collaboration with the National Geodetic Survey. This was necessary to ensure that calculated elevations resulting from the survey were of the highest accuracy possible - particularly important with regard to determining actual floodwall elevations at each levee breach. Using this network of base stations for postprocessing of the kinematic GPS data, we collected approximately 15 local control points at each levee site with the two roving GPS receivers. Each point was occupied for approximately 5 to 10 minutes (300 to 600 measurements), providing postprocessed coordinate accuracies on the order of a few centimeters.

Using the collection of local control points, we georeferenced the lidar datasets by finding the best fit of the identified cultural features within the scans to the surveyed GPS control points. This transformed the locally referenced data collected at the time of the reconnaissance to geodetic coordinates referenced to the North American Datum of 1983 (NAD83) ellipsoid (CORS 96 - EPOCH 2002.0000) and projected to

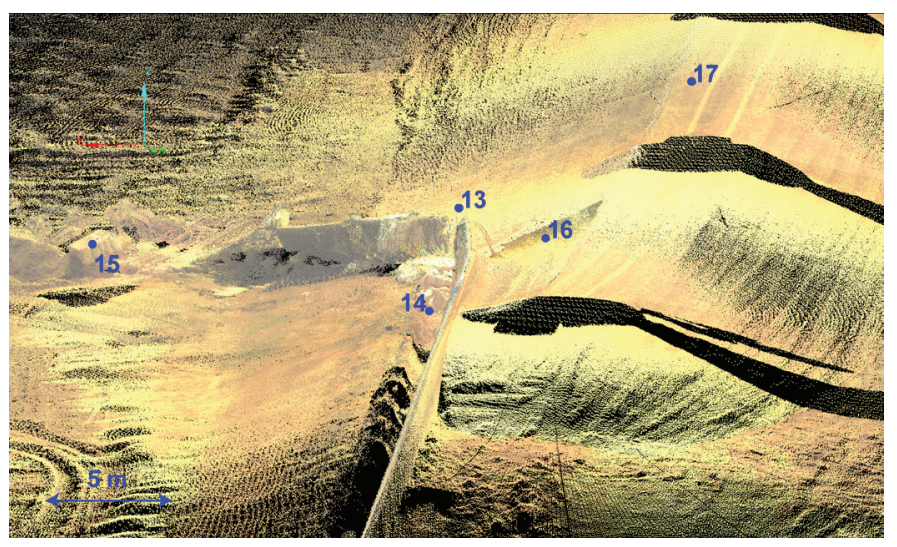

Figure 5. Lidar image oblique view (same site and viewpoint as fig. $4 B$ ) of multiple scans (scan locations 13-17) at the IHNC North Breach required to fill shadow zones. Scour trench behind floodwall was captured from scan location 14. 
Table 2. Data accuracy.

[IHNC, Inner Harbor Navigation Canal (Industrial Canal); GIWW, Gulf Intracoastal Waterway; MRGO, Mississippi River Gulf Outlet]

\begin{tabular}{clccc}
\hline $\begin{array}{c}\text { Lidar Site } \\
\text { Number }\end{array}$ & \multicolumn{1}{c}{ Site Description } & $\begin{array}{c}\text { Single Scan } \\
\text { Error }(\mathbf{c m})\end{array}$ & $\begin{array}{c}\text { Multi-scan Error } \\
(\mathbf{c m})\end{array}$ & $\begin{array}{c}\text { Georeferenced } \\
\text { Model Error (cm) }\end{array}$ \\
\hline 1 & 17th Street Canal Levee Breach & 2.5 & 7.7 & 23.3 \\
2 & Orleans Canal Pump Station Spillway Breach & 2.5 & 10.4 & 10.9 \\
3 & North London Avenue Canal Levee Breach & 2.5 & 9.5 & 19.6 \\
& Lakefront Airport Levee Transition Breach and & 2.5 & 10.7 & 13.3 \\
4 & $\quad$ Floodwall Scour & & 15.3 & 164.2 \\
5 & IHNC-East Levee Breaches & 2.5 & 16.4 & 164.3 \\
6 & IHNC-West - Port of New Orleans Levee Breaches & 2.5 & 11.4 & 116.6 \\
7 & GIWW-MRGO Earth Levee Erosion & 2.5 & 14.4 & 75.8 \\
\hline
\end{tabular}

the Universal Transverse Mercator (UTM) coordinate system for southeast Louisiana (Zone 15 for sites 1 through 6, and Zone 16 for sites 7 and 8). Vertical coordinates were subsequently converted to North American Vertical Datum of 1988 (NAVD88) heights using the GEOID 2003 separation model.

\section{Results}

\section{Data Coverage}

The data presented in this report consist of a total of 143 individual scans of levees (table 3 ). The red boundary lines shown in figures 7 through 14 define the approximate bounds of highly detailed continuous lidar data at each site from each scan location (yellow dots). Considerable data exist outside of these bounds, though they are not continuous and may have substantial shadow effects. In general, point-to-point spacing of individual lidar data points within the outlined areas is on the order of $2.5 \mathrm{~cm}$, providing an extremely dense coverage of all objects within each site (fig. 15). This high-resolution point density is the primary benefit of terrestrial lidar data collection-objects not identified and measurements not previously made during the preliminary field reconnaissance can be virtually revisited and calculated in the datasets. The following brief descriptions provide information about particular features viewable in each dataset.

At the 17th Street Canal levee breach (site 1, fig. 7), we collected data in and around the main levee breach, including documentation of damaged residences approximately $150 \mathrm{~m}$ to the east of the breach along Bellaire Drive. Unfortunately, the incipient failure of the west bank of the canal is not documented in great detail by the terrestrial lidar datasets. At the time of data collection, an emergency repair earth embankment was in place to close the breach; however, the datasets still document the location of such items as the final, translated location of the earth embankment and the scour area to the east of the canal formed by the in-rushing waters of the breach. At the Orleans Canal pump station spillway (site 2, fig. 8), we collected data covering the spillway, surrounding floodwalls, and the east and north sides of the pump station building. Point coverage of the North London Avenue Canal breach (site 3, fig. 9) includes data from both sides of the canal detailing the main (west side) levee breach, the incipient failure on the east side of the canal, and a 250-m length of the damaged neighborhood immediately to the east of the canal.

At the Lakefront Airport (site 4, fig. 10), we collected data of the transition breach area, from the concrete floodwall to the earth railroad line embankment, and also of nearby scour trenches formed by the Lake Pontchartrain storm surge overtopping the concrete floodwall. At the IHNC-East breaches (site 5, fig. 11), we collected data over a length of approximately 1,160 m covering both levee breaches. Details of the breaches, the distorted sheet-pile walls that were excavated by floodwaters, and the surrounding, obliterated neighborhood are all contained in the scan data.

Point coverage of the IHNC West-Port of New Orleans breaches (site 6, fig. 12) includes data over a distance of $600 \mathrm{~m}$ along both sides of the floodwall and earth embankment at the south end of the port. Interesting details viewable in the dataset include the 30-m-long scour hole left by the erodible embankment breach, the $45-\mathrm{m}$-long breach of the toppled floodwall, and the general disarray of the port facilities and shipping containers strewn about the area. Along the GIWW-MRGO earth levee (site 7, fig. 13), we collected data of an approximately 240 -m length of the earth levee, including details of erosion generated by the overtopping storm surge on the back (protected side) of the earth levee. Point coverage of the GIWW-MRGO floodwall scour (site 8, fig. 14) includes 
Table 3. Terrestrial lidar data files of Hurricane Katrina levee failures in New Orleans.

[IHNC, Inner Harbor Navigation Canal (Industrial Canal); GIWW, Gulf Intracoastal Waterway; MRGO, Mississippi River Gulf Outlet]

\begin{tabular}{|c|c|c|c|c|c|c|}
\hline $\begin{array}{l}\text { Lidar } \\
\text { Site } \\
\text { Number }\end{array}$ & Site Description & File Name & $\begin{array}{l}\text { Number of } \\
\text { Scan Files }\end{array}$ & $\begin{array}{l}\text { Number of } \\
\text { Data Points }\end{array}$ & $\begin{array}{c}\text { Compressed File } \\
\text { Size } \\
\text { (Mb) }\end{array}$ & $\begin{array}{l}\text { Approx. Un- } \\
\text { compressed } \\
\text { File Size }\end{array}$ \\
\hline 1 & $\begin{array}{l}\text { 17th Street Canal Levee } \\
\text { Breach }\end{array}$ & 17th_canal.zip & 17 & $20,543,876$ & 420 & 1350 \\
\hline 2 & $\begin{array}{l}\text { Orleans Canal Pump Sta- } \\
\text { tion Spillway Breach }\end{array}$ & orleans_canal.zip & 7 & $10,366,309$ & 207 & 650 \\
\hline 3 & $\begin{array}{l}\text { North London Avenue } \\
\text { Canal Levee Breach }\end{array}$ & north_london_canal.zip & 28 & $30,900,773$ & 600 & 1950 \\
\hline 4 & $\begin{array}{l}\text { Lakefront Airport Levee } \\
\text { Transition Breach and } \\
\text { Floodwall Scour }\end{array}$ & lakefront_airport.zip & 14 & $12,812,512$ & 278 & 870 \\
\hline 5 & $\begin{array}{l}\text { IHNC-East Levee } \\
\text { Breaches }\end{array}$ & IHNC-east.zip & 25 & $29,557,611$ & 585 & 1870 \\
\hline 6 & $\begin{array}{l}\text { IHNC-West - Port of } \\
\text { New Orleans Levee } \\
\text { Breaches }\end{array}$ & IHNC-west_port.zip & 19 & $15,987,491$ & 323 & 1010 \\
\hline 7 & $\begin{array}{l}\text { GIWW-MRGO Earth } \\
\text { Levee Erosion }\end{array}$ & $\begin{array}{l}\text { GIWW-MRGO_earthle- } \\
\text { vee.zip }\end{array}$ & 13 & $7,521,920$ & 150 & 470 \\
\hline 8 & $\begin{array}{l}\text { GIWW-MRGO Floodwall } \\
\text { Scour }\end{array}$ & $\begin{array}{l}\text { GIWW-MRGO_flood- } \\
\text { wall.zip }\end{array}$ & 20 & $6,584,737$ & 134 & 410 \\
\hline
\end{tabular}
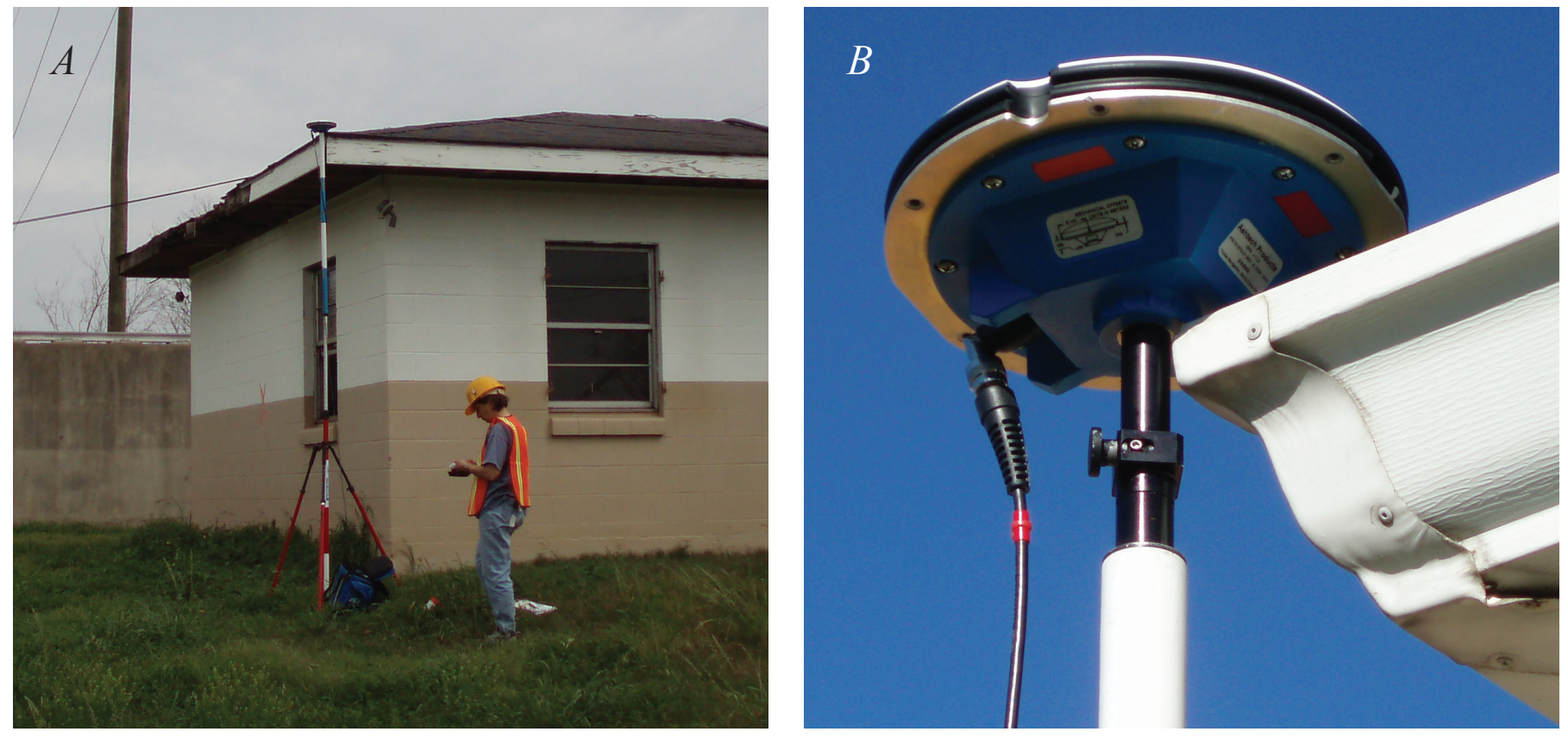

Figure 6. Corners of buildings $(A)$ and gutters $(B)$ provide well-defined global positioning system (GPS) survey points for georeferencing the lidar point-cloud datasets. 


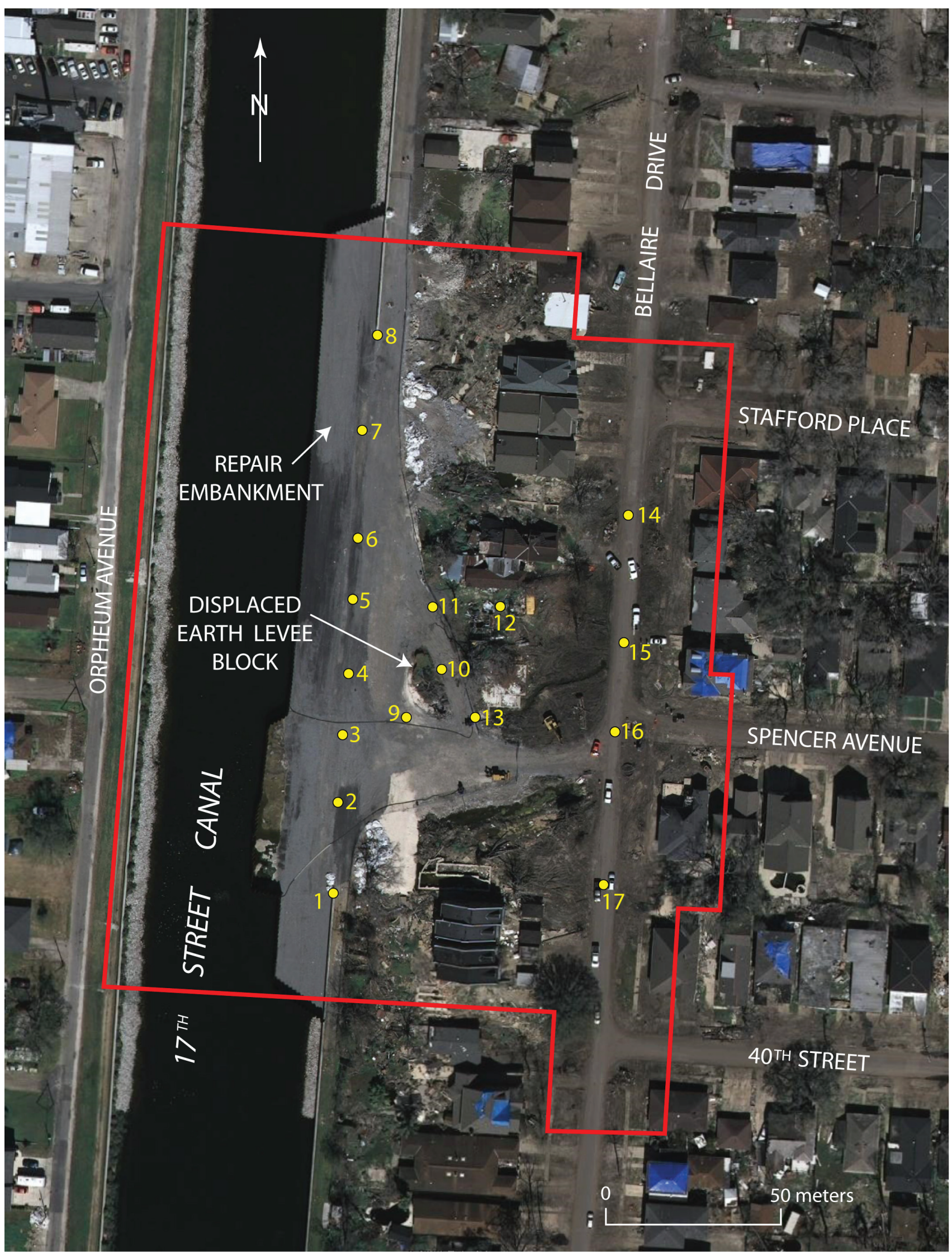

Figure 7. Site 1-17th Street Canal levee breach. Numbered dots indicate locations of scan positions. Red outline indicates area of lidar data coverage. (Photo source: Google Earth-USGS image.) 


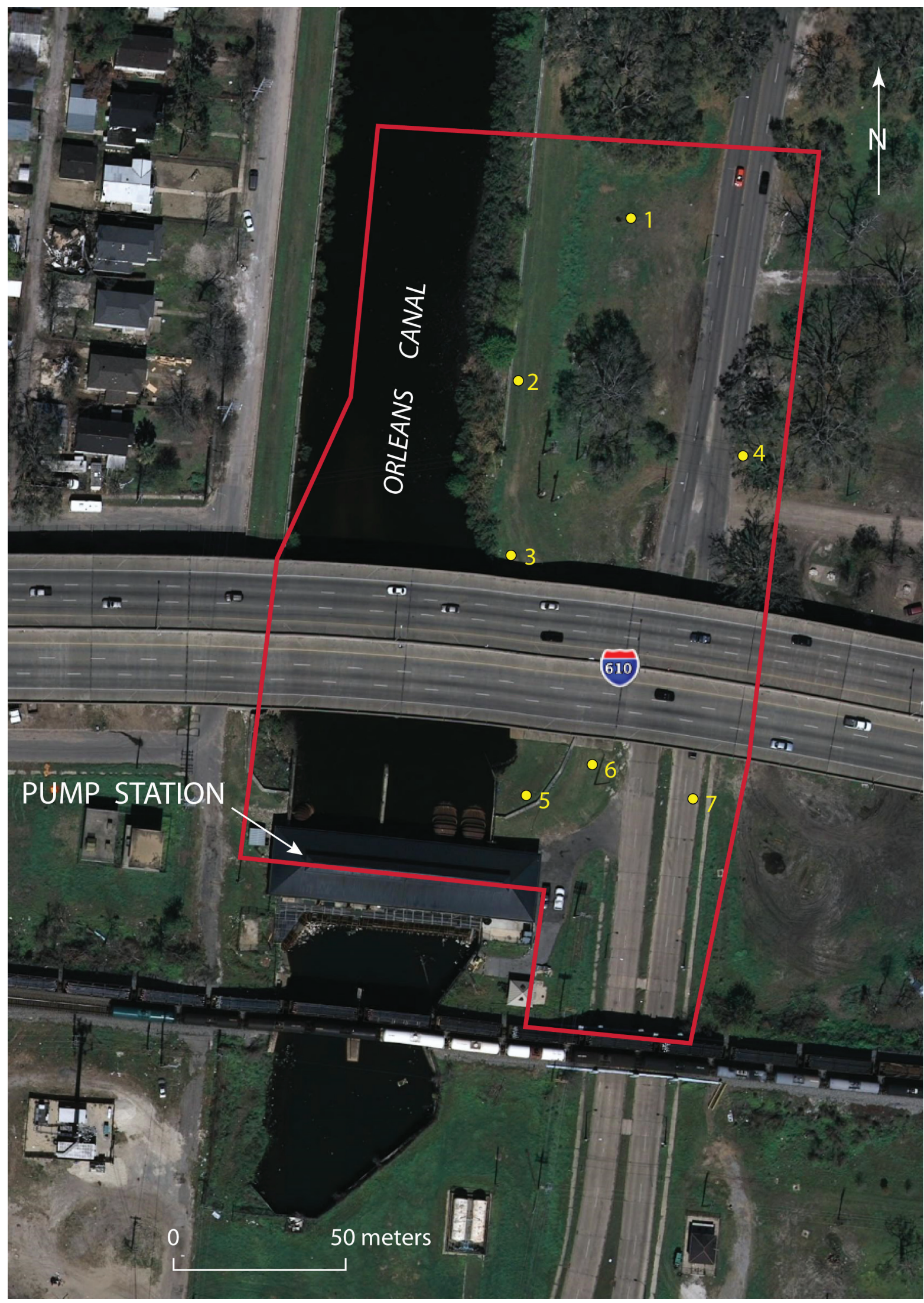

Figure 8. Site 2-Orleans Canal pump station spillway breach. Numbered dots indicate locations of scan positions. Red outline indicates area of lidar data coverage. (Photo source: Google Earth-USGS image.) 


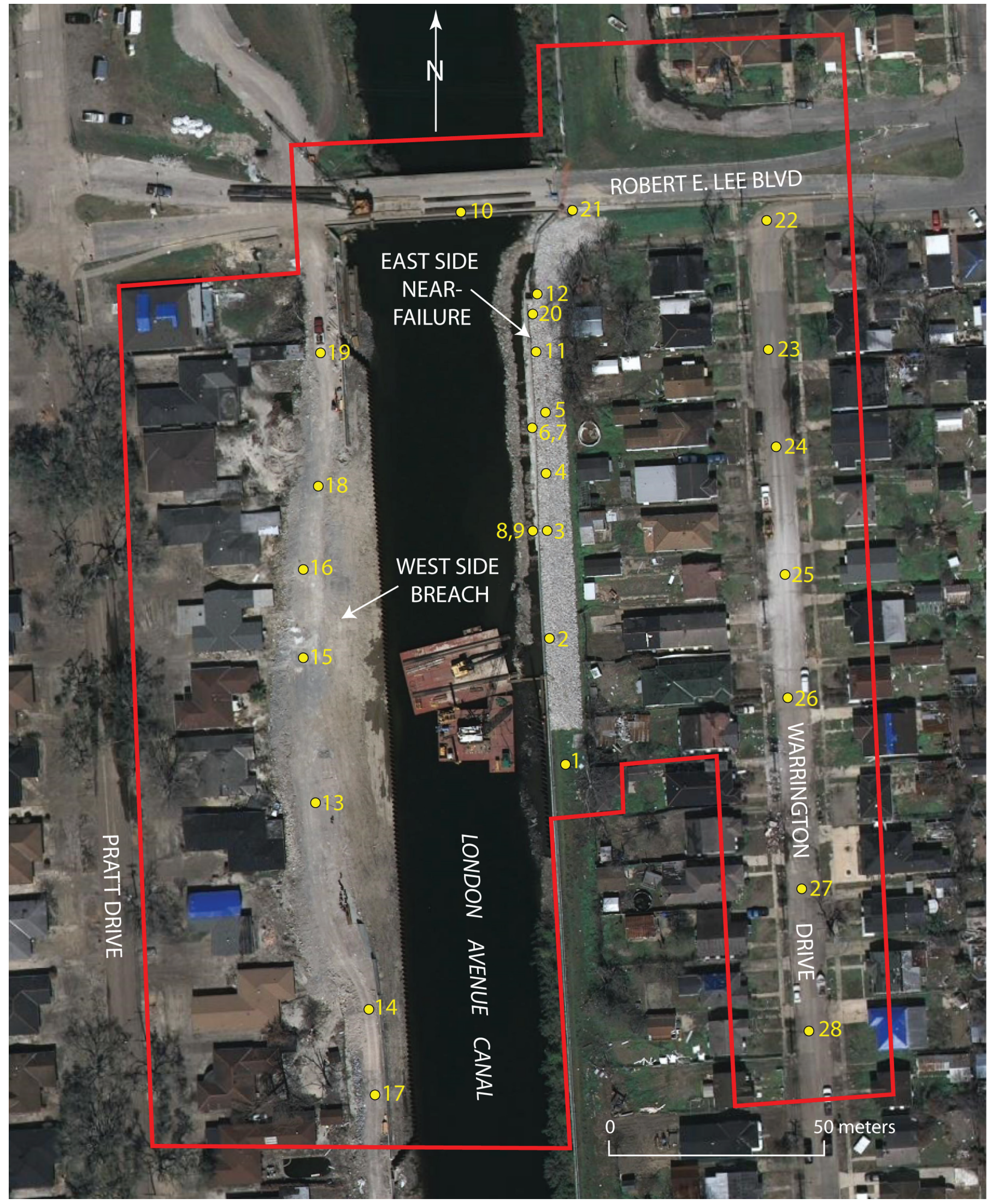

Figure 9. Site 3-North London Avenue Canal levee breach. Numbered dots indicate locations of scan positions. Red outline indicates area of lidar data coverage. (Photo source: Google Earth-USGS image.) 


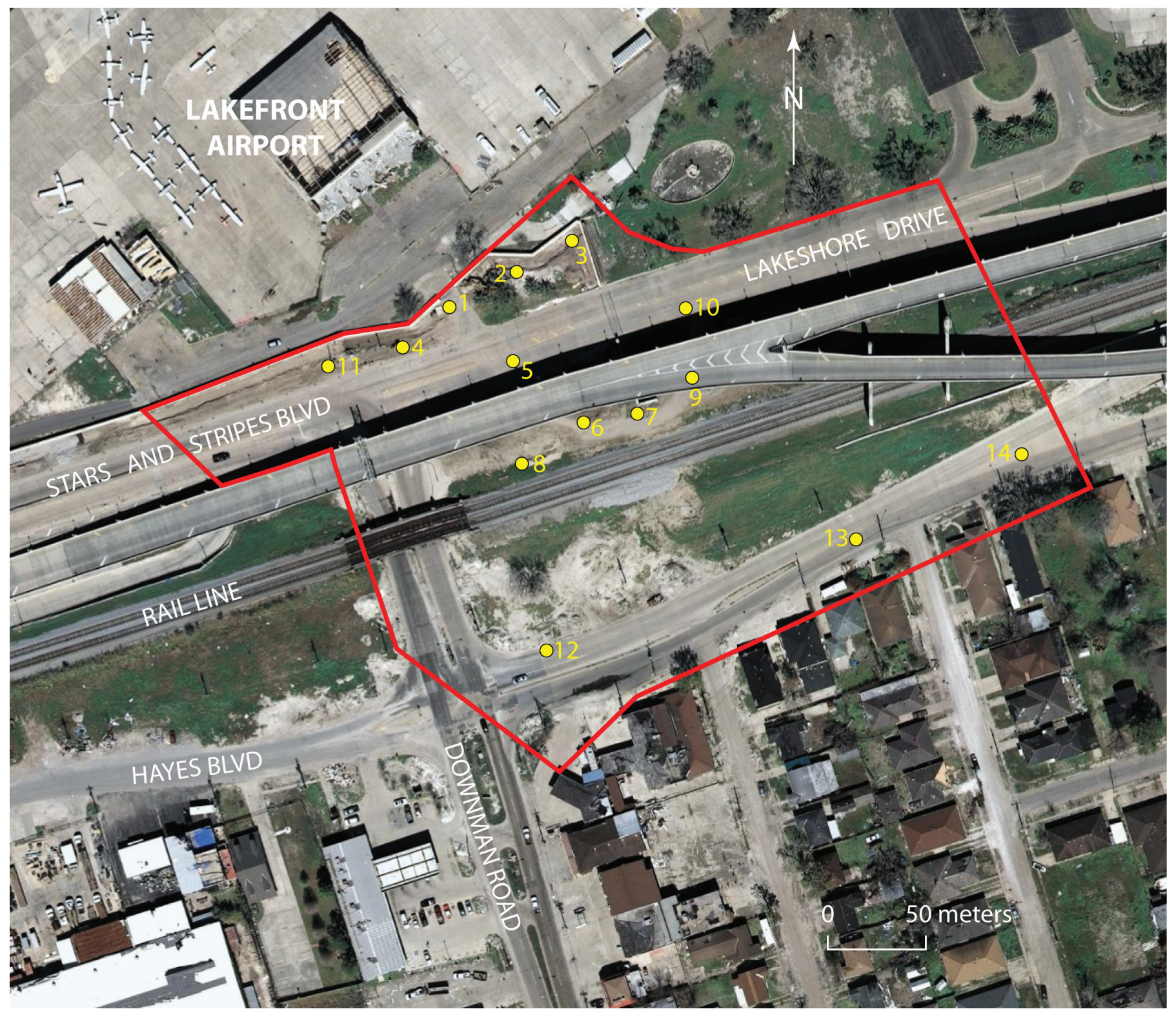

Figure 10. Site 4-Lakefront Airport levee transition breach and floodwall scour. Numbered dots indicate locations of scan positions. Red outline indicates area of lidar data coverage. (Photo source: Google Earth-USGS image.) 


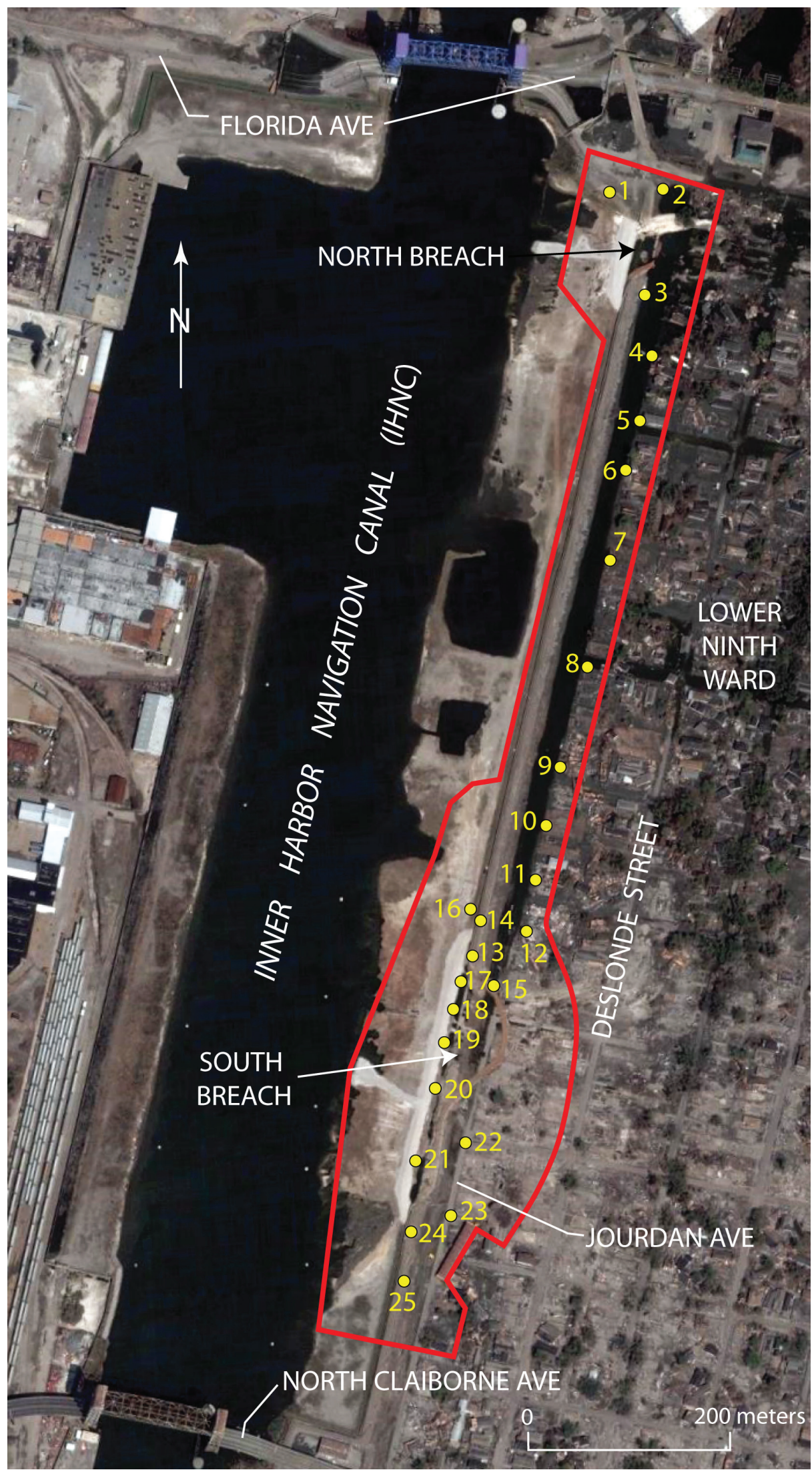

Figure 11. Site 5-Inner Harbor Navigational Canal (IHNC)-East levee breaches. Numbered dots indicate locations of scan positions. Red outline indicates area of lidar data coverage. (Photo source: Google Earth-Digitalglobe image.) 


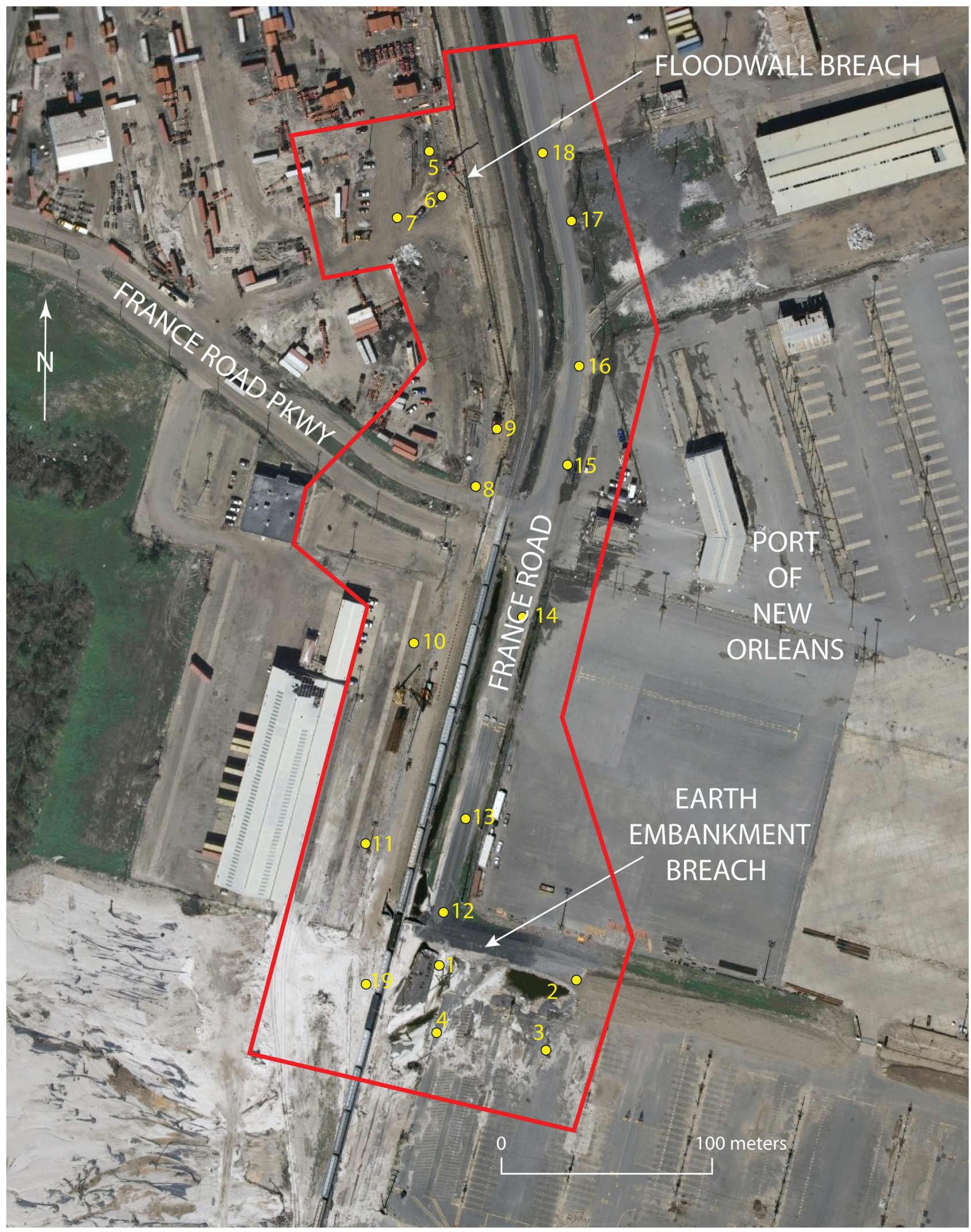

Figure 12. Site 6-Inner Harbor Navigational Canal (IHNC)-West-Port of New Orleans levee breaches. Numbered dots indicate location of scan positions. Red outline indicates area of lidar data coverage. (Photo source: Google Earth-USGS image.) 


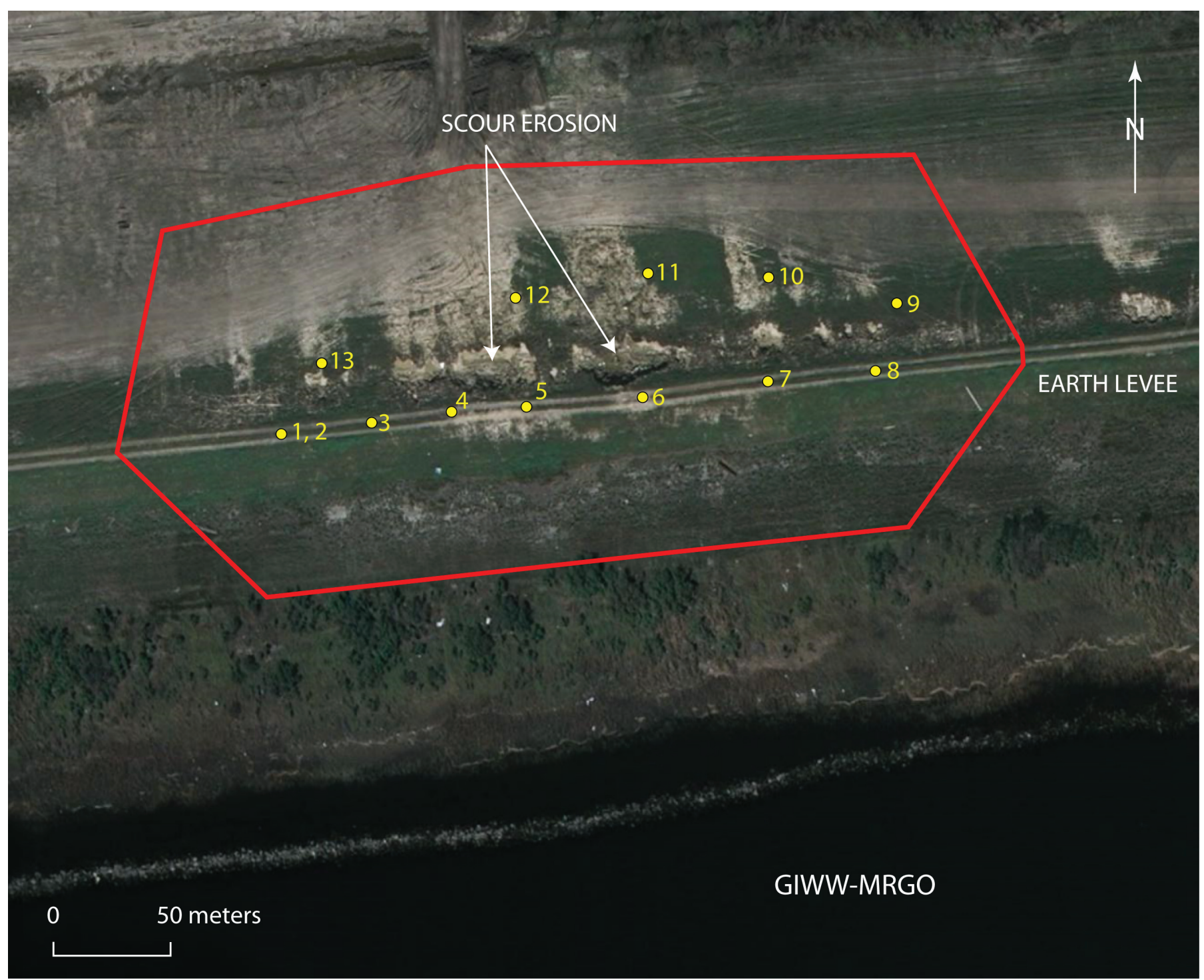

Figure 13. Site 7-Gulf Intracoastal Waterway-Mississippi River Gulf Outlet (GIWW-MRGO) earth levee erosion. Numbered dots indicate locations of scan positions. Red outline indicates area of lidar data coverage. (Photo source: Google Earth-USGS image.) 


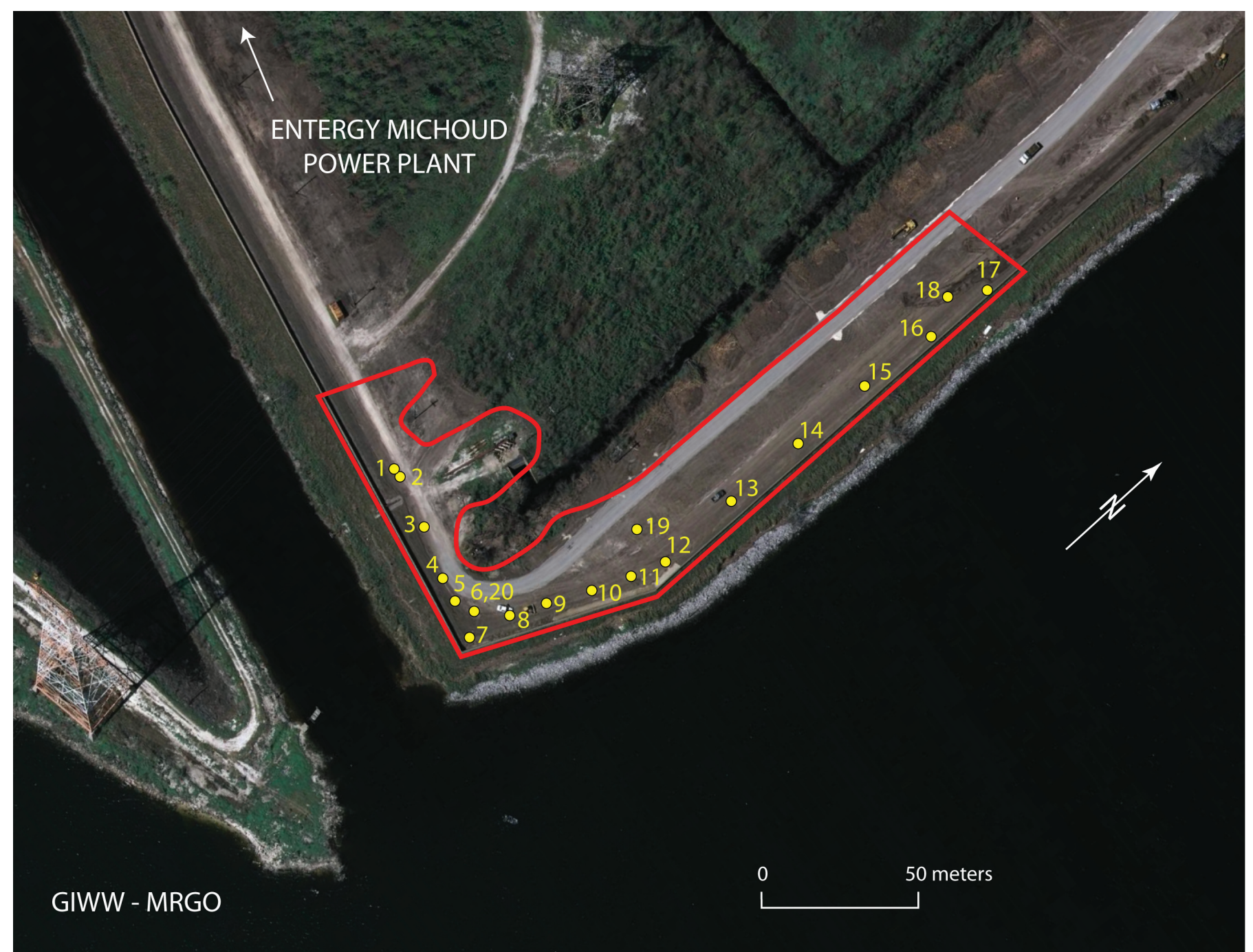

Figure 14. Site 8-Gulf Intracoastal Waterway-Mississippi River Gulf Outlet (GIWW-MRGO) floodwall scour. Numbered dots indicate locations of scan positions. Red outline indicates area of lidar data coverage. (Photo source: Google Earth-USGS image.)

details of approximately $420 \mathrm{~m}$ of the floodwall, showing details of scour trench development on the protected side of the wall.

\section{Data Accuracy}

The accuracy of the point clouds is dependent on several factors, each of which influences the utility of the data. These factors include laser error, registration processing error, and georeferencing error. Measurements made within a single scan are only influenced by the laser error, whereas measurements made within neighboring (adjoining) scans within a single site are dependent on both the laser and registration processing errors (that is, the "multi-scan error") that influence the accuracy of fit between the scans. Finally, measurements made between the terrestrial lidar datasets and other forms of georeferenced data (such as orthometric photographs and aerial lidar datasets) are dependent on all three types of error (laser, registration processing, and georeferencing errors), which results in a georeferenced model error. Here, we provide analyses of each of these errors calculated in terms of a three dimensional error for each site (table 2).

We assume a laser error of $2.5 \mathrm{~cm}$ for all of the datasets based on the manufacturer-provided error estimate (Riegl, 2008). We take this to be a moderately conservative value given the results of calibration tests on our unit $(1.5 \mathrm{~cm})$ and independent studies by Boehler and others (2003) on an identical instrument, which obtained maximum absolute error values of $2.71 \mathrm{~cm}$.

Our estimates of registration error are based on the bestfit registration algorithms used to bring adjoining scans into a common, local reference frame. These algorithms vary for each site depending on the degree and density of data overlap between the scans and with the type of data collected. Typically, registration of adjoining scans with overlapping data consisting of angular features such as buildings and bridges resulted in lower errors compared to those having less 

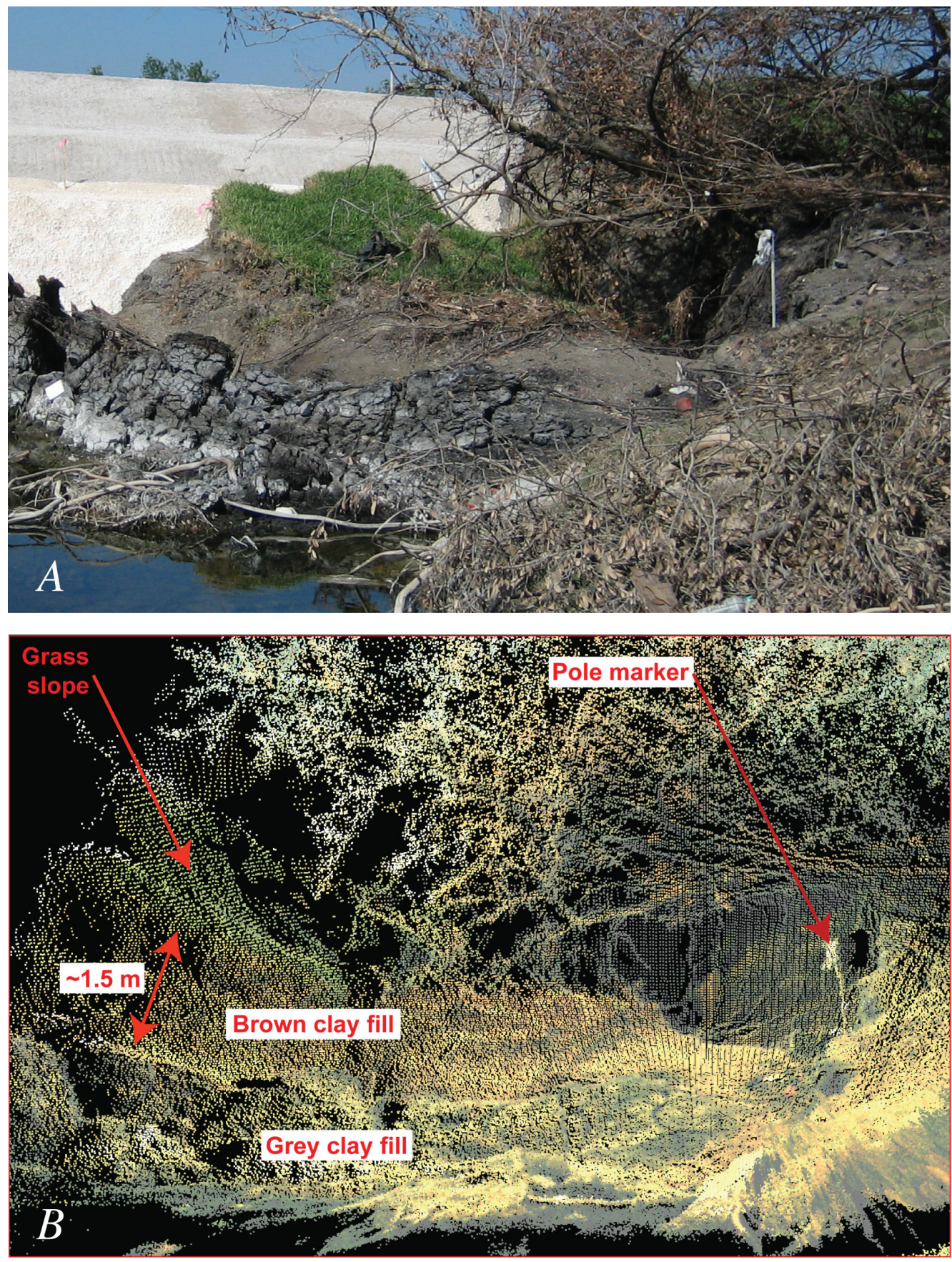

Figure 15. Image $(A)$ and high resolution terrestrial lidar data coverage image $(B)$ of displaced block stratigraphy from the 17th Street Canal levee breach.

identifiable features such as soil-covered ground and vegetation. Estimates of these errors are a result of the output of the I-SiTE Studio software program (I-SiTE, 2008) and range from $7.2 \mathrm{~cm}$ to $16.3 \mathrm{~cm}$. Combined with the laser error and computed as independent errors (that is, the final error is computed as the sums of the squares of the contributing errors), the multi-scan error varies between $7.7 \mathrm{~cm}$ and 16.4 $\mathrm{cm}$ for the datasets (table 2).

We estimated georeferencing errors differently for sites 1 through 5 and sites 6 through 8 because of the lack of precisely surveyed data at the latter sites. For sites 1 through 5, georeferenced data was collected and referenced to fixed locations visible within the scan features using geodetic-quality GPS receivers. The errors introduced by this method range between $3.1 \mathrm{~cm}$ and $22.2 \mathrm{~cm}$, with one exception at site 5 (IHNC-East Levee Breaches). Here, the long linear trend of the data, combined with the lack of sufficient surveyed control points resulting from ongoing levee repair activities at the site between the original reconnaissance (October 2005) and the GPS survey reconnaissance 


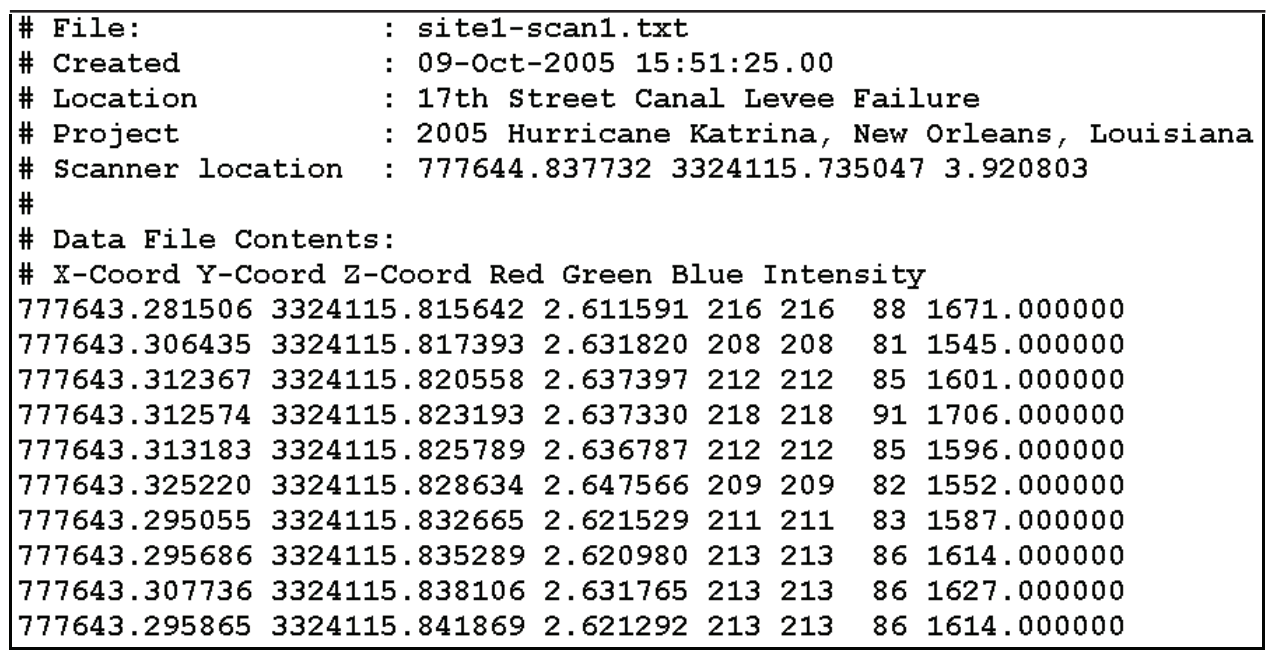

Figure 16. Example of data format for terrestrial lidar digital files included with this report.

(March 2006), resulted in a georeferenced fit of the data of only $163.5 \mathrm{~cm}$. At sites 6 though 8 , georeferencing was obtained through the location of five or six points visible in both the scan data and in Google Earth imagery. Because of the coarseness of the imagery data at this scale, we obtained error estimates of between $74.4 \mathrm{~cm}$ and $163.5 \mathrm{~cm}$.

We combined each of the three types of errors assuming an independent error contribution from each (again, estimating the final combined error as the sums of the squares of the contributing errors). Final georeferenced model fit for the eight sites, including all laser, registration, and georeferencing errors, range from $10.9 \mathrm{~cm}$ to $164.3 \mathrm{~cm}$ (table 2).

\section{Electronic Data Format}

The processed terrestrial lidar data for each site have been formatted and compressed into electronic files for public dissemination (table 3). Because the files contain the threedimensional coordinates of millions of individual surveyed points, these files should be opened and manipulated with caution-downloading may take time, depending on connection speed. In addition, specialized software may be necessary to view the point clouds. Whereas we utilized one such piece of software (I-SiTE Studio), other lidar, CAD, and GIS application packages are available.

The data for each site is organized into individual compressed files (.zip). The compressed files contain a series of text files (.txt), each containing the data for a particular scan location (shown in figs. 7-14). The text files, in turn, contain the three-dimensional $\mathrm{x}, \mathrm{y}, \mathrm{z}$ coordinates, color (red, green, and blue) and intensity values for the points collected at the site and are organized with the following data format (fig. 16): [X coordinate Y coordinate $\mathrm{Z}$ coordinate Red Color Green Color Blue Color Intensity]. Note that the coordinate values are provided according to their numerical precision (to six decimal places), as opposed to their analyzed accuracy, to account for points that would otherwise be located at identical locations due to the extremely high point density of each dataset.

Each point represents the coordinates of any number of features within the scene, including bare ground, levee walls, vegetation, houses, and vehicles. To obtain coordinate values for specific morphologic features captured within each scan, additional filtering steps are necessary, but these depend on the required data use (for example, only bare ground, only levee walls, bare ground and levee walls, and so forth). This step is therefore left to be performed by interested parties using any number of available data filtering algorithms and software packages.

\section{Discussion}

Using appropriate software applications, the terrestrial lidar data point clouds can be manipulated and viewed from virtually any angle, providing a comprehensive tool for investigating a site's topography and any number of unique particularities. The terrestrial lidar data can be used to measure translational and rotational displacement, make relative measurements of elevation differences, and highlight site features that may have gone unrecognized in the original site visit or have been destroyed since the original data collection effort. Examples of several of the geomorphologic aspects of the levee failures visible in the lidar data are provided here both to highlight the use of the data and as examples of the leveefailure modes that occurred in New Orleans.

\section{7th Street Canal Levee Breach}

The 17th Street Canal levee breach occurred as a translational failure of the embankment from excessive hydrostatic pressures on the flood side of the water-filled canal (Seed and others, 2008c). Measurement of displacement along the 17th Street Canal breach can be made using the lidar data by 

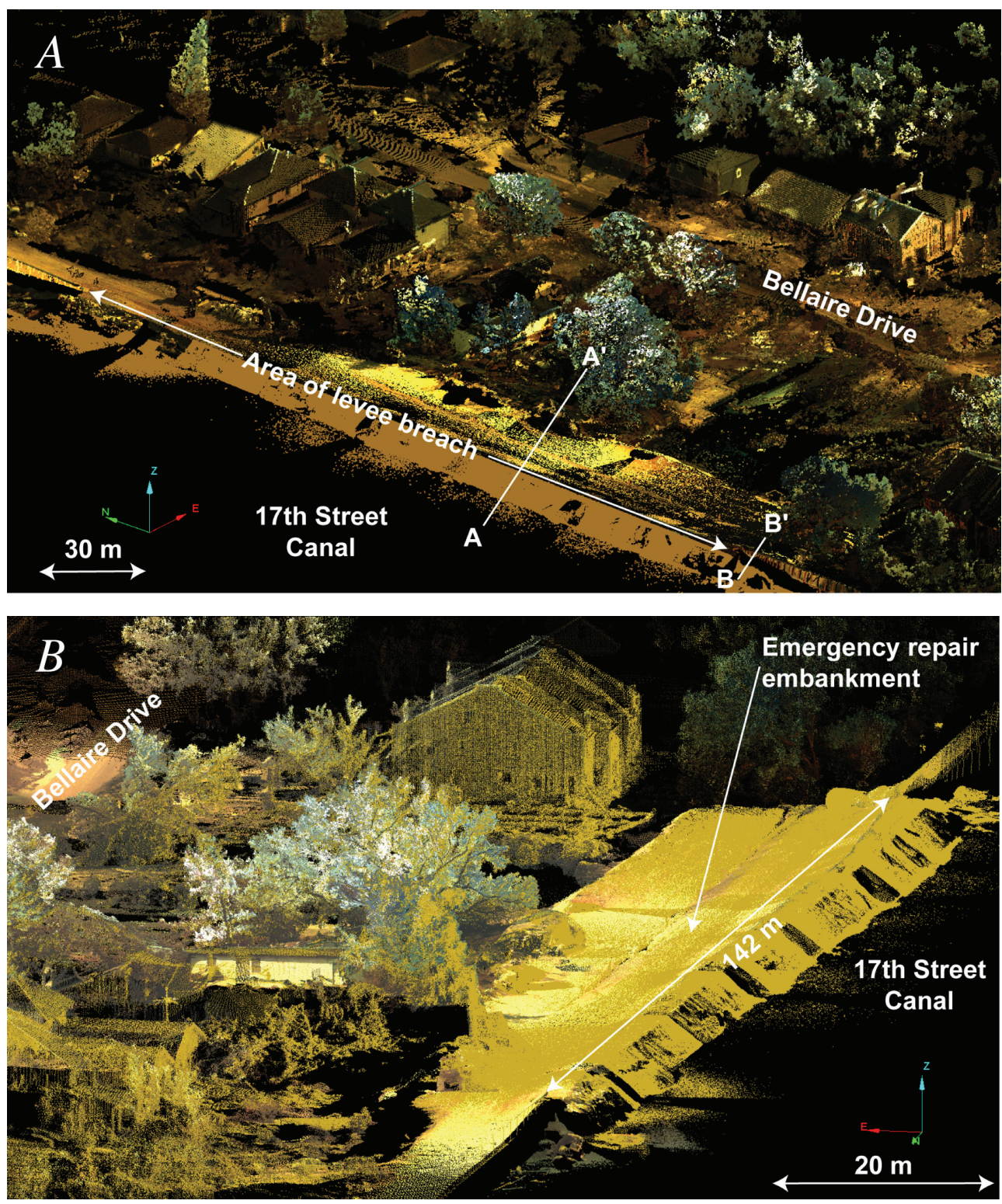

Figure 17. Overview oblique lidar image $(A)$ of the 17 th Street Canal area in the vicinity of the breach and close-up view lidar image $(B)$ of the breach area showing key features.

identifying the blocks of ground formerly within the intact levee that slid eastward toward the protected side of the levee. In an overview image of the point cloud dataset (fig. 17A), the dense cluster of points visible in the center of the image highlights the levee breach and surrounding surviving houses. Viewing the data from a different perspective, a total breach width of 142 meters is calculated (fig. 17B). In cross-section view (fig. 18), and close-in to the levee breach, a segment of the remaining I-wall has been aligned with the crest of the replacement structure and a section of the translated earth levee. With this perspective, the geometry of the emergency repair embankment (constructed immediately following the breach and before terrestrial data collection) is clearly visible, as is the magnitude of the displacement (approximately $14 \mathrm{~m}$ ) of several earth blocks that moved away from the levee break during failure. The calculation is performed through the identification of the before and after locations of a chain link fence visible in the data (fig. 18).

\section{Orleans Canal Pump Station Spillway Breach}

The Orleans Canal pump station spillway breach highlights one of several examples where floodwaters were allowed into the city by a lack of engineering design. Rather than construct either an end-canal floodgate at the canal's northern end, or a closed-system floodwall at the southern end, an approximately 65-meter gap with an elevation 1.3 meters below the surrounding floodwall elevation was constructed. The purpose of the gap was to prevent floodwaters from reaching a height in which the 


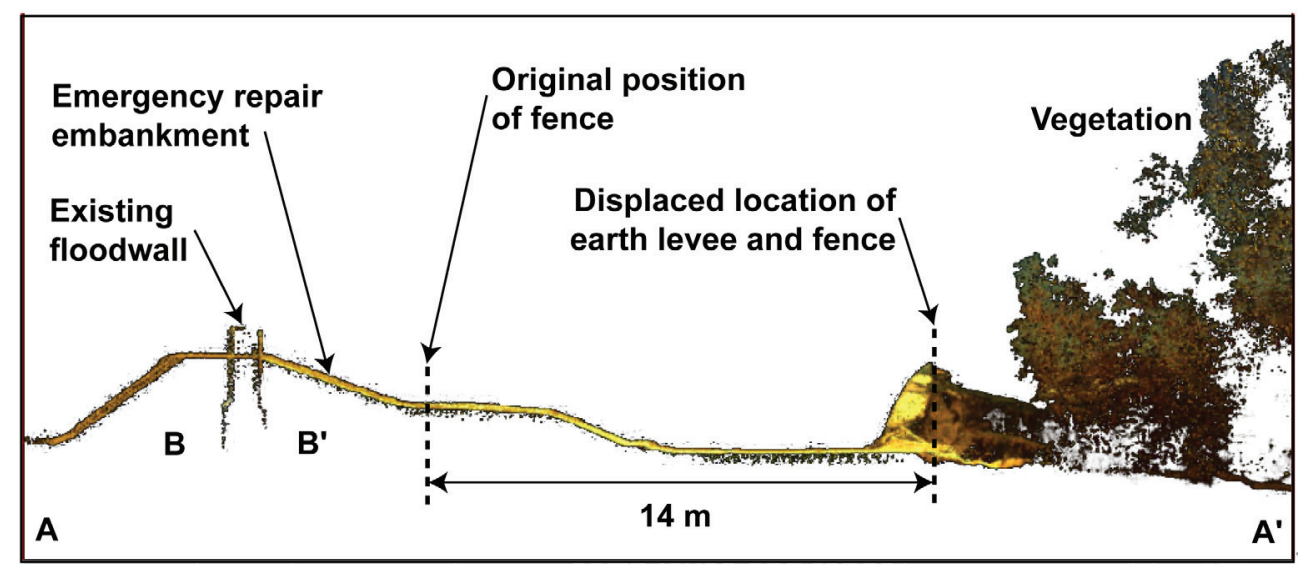

Figure 18. Lidar image cross section of the 17th Street Canal breach looking northward (crosssection $A-A^{\prime}$, fig. 17A). The existing floodwall in this image is offset to the south (out of the page) from the displaced earth levee section (see cross-section B-B', fig. 17A).

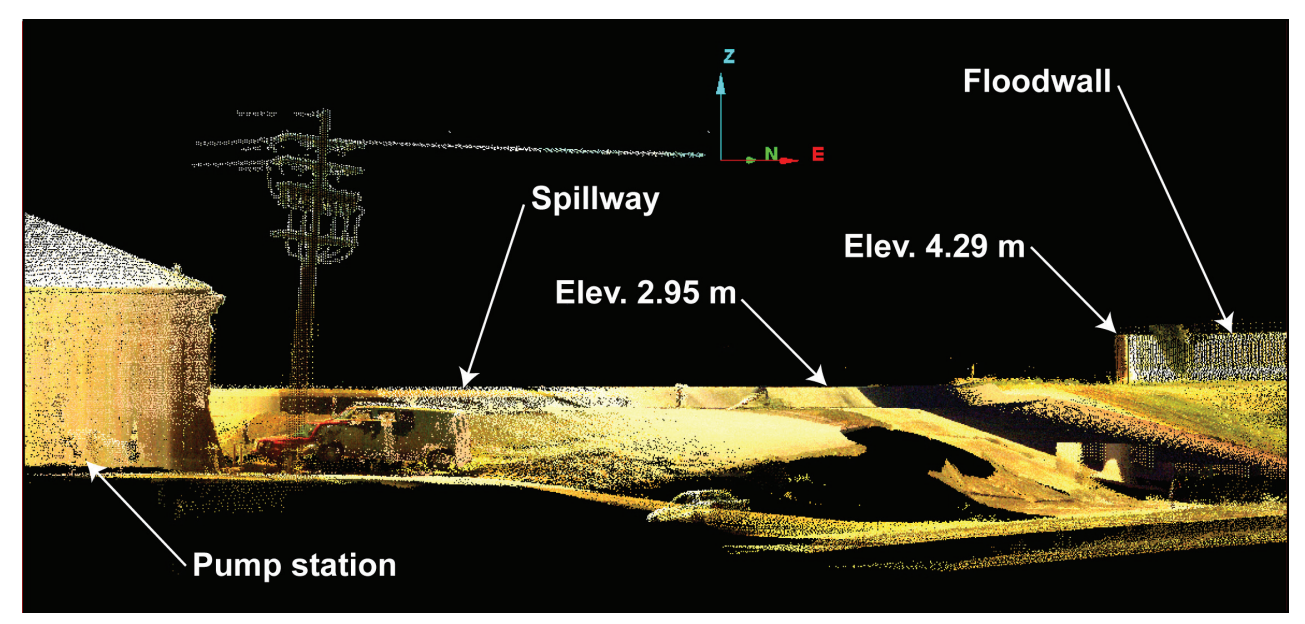

Figure 19. Lidar image of Orleans Canal pump station and floodwalls showing discrepancy between as-built elevations of spillway and adjacent floodwall.

weak masonry walls of the adjacent pump station could collapse (ILIT, 2006). Instead, the gap allowed flooding of the city, directly contradictory to the intended purpose of the pump station. In the lidar data, this gap is clearly visible (fig. 19).

\section{North London Avenue Canal Levee Breach}

In the northern area of the London Avenue Canal, one complete breach and another near-failure occurred along the west and east sides of the canal, respectively. Here, several key reconnaissance items are visible in the lidar datasets. In addition to the details of the levee failure and distressed section, the data provide definitive information on the relative elevations of different portions of the levee protection system. These provide clear evidence that the London Avenue Canal floodwalls were not overtopped by rising water in the canal, as was initially proposed as the likely failure mechanism of the breach. Rather,
Seed and others (2008d) have shown that this breach occurred because of lateral instability of the combined earth levee-concrete floodwall system, likely exacerbated by a loss of strength through water underseepage from the canal outwards.

A significant difference in height between the lower unwalled bridge abutment and floodwall located to the immediate north prevented water from overtopping these levees. On the northeast corner of the bridge abutment, near the north levee wall, lidar surveys indicate an approximate elevation difference of $1.5 \mathrm{~m}$ at this location (fig. 20). Rising water in the canal from Lake Pontchartrain (fig. 2), and north of the Robert E. Lee Blvd. bridge crossing the canal, would have overtopped the bridge railing before any overtopping of the floodwall occurred south of the bridge and in the vicinity of the west levee failure and east levee near-failure.

In the area of the incipient failure on the east side of the canal, south of the Robert. E. Lee bridge crossing and opposite the main north London Avenue Canal levee breach, the 

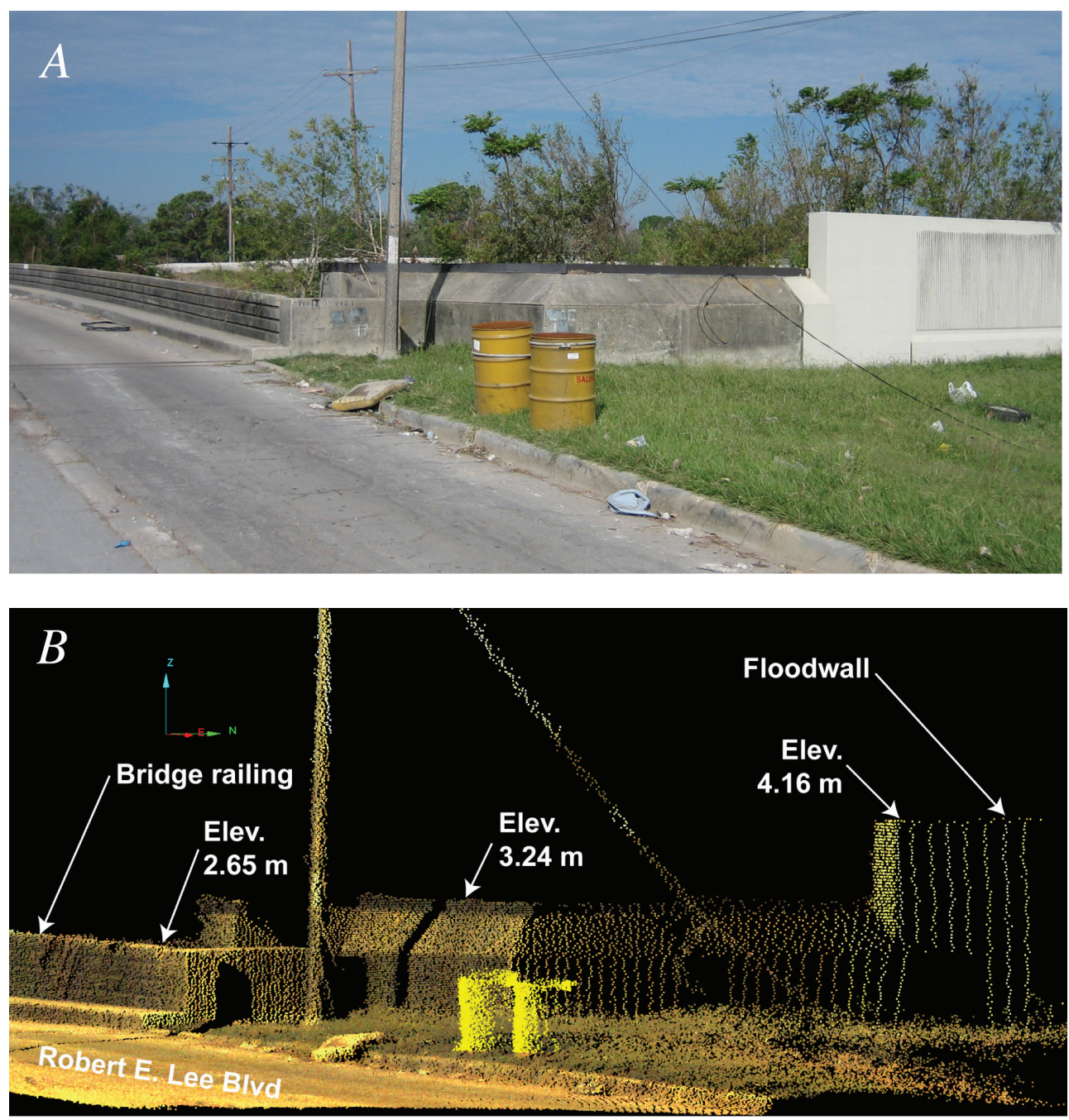

Figure 20. $A$, Lack of floodwall continuity along the northeast abutment of the Robert $\mathrm{E}$. Lee Blvd. bridge over the London Avenue Canal (site 3). $B$, Measurements from the lidar data provide exact elevations of each floodwall section relative to the vertical datum.

terrestrial lidar dataset provides additional details of the levee failure mechanisms. Observations and lidar visualizations show that the floodwall suffered rotational displacement and near failure (fig. 21A). Because of the precarious nature of the floodwall in this location, it has been shown that if the levee failure located directly across from this area had not occurred, this site might have failed instead (Seed and others, 2008d). Viewed from the south - and preserved in incipient failure by the lidar data (fig. 21B), - the distressed wall leans toward the levee maintenance road and the protected side of the levee. Thin slices of the point-cloud data orthogonal to the alignment of the floodwall show the increase in levee rotation from $2^{\circ}$ at the south portion of the distressed region to $8^{\circ}$ at the position of maximum distress located approximately $50 \mathrm{~m}$ to the north. The cross sections also show the geometry of a "gap" on the floodside of the wall, formed from rotation of the wall itself. Seed and others (2008d) show that this gap resulted in the development of water pressures along the buried sheet-pile curtain beneath the wall, further leading to instability.

\section{IHNC-East, South Levee Breach}

A final example of the use of the lidar data is shown by the analysis of scour trench dimensions at the east side IHNCsouth breach (fig. 22). Here the data are viewed in cross section to calculate the depth of scour adjacent to the I-wall and vertically into the embankment so that a direct comparison of the scour depth to sheet-pile embedment can be made. Detailed geotechnical analyses by Seed and others (2008b) have shown that the failure mode at this location was more likely associated with underseepage-induced lateral translation failure of the earth embankment portion of the levee. However, their analyses also indicate that overtopping-caused lateral floodwall toppling related to the formation of a scour 

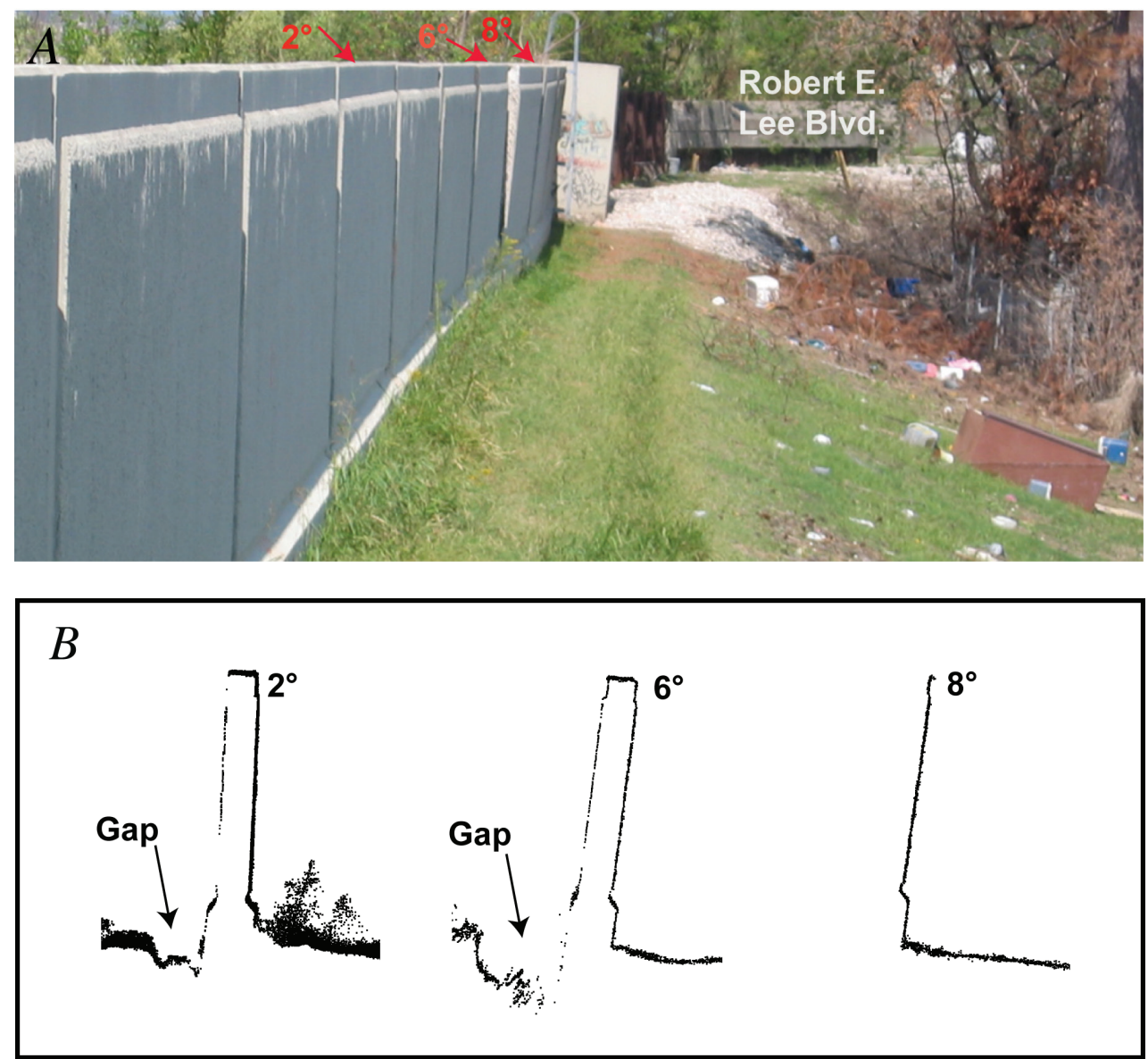

Figure 21. $A$, Leaning floodwall on the east side of the London Avenue Canal (site 3). B, Lidar image cross sections through three segments of the floodwall, showing rotational deformation toward the protected side of the levee.

trench on the protected side of the levee cannot be ruled out; this is the preferred failure-mechanism interpretation of the Interagency Performance Evaluation Task Force headed by the U.S. Army Corps of Engineers (IPET, 2007). We present the following analyses to show the utility of the lidar data for measuring scour-trench depth and width in the hope that they may assist with any future analyses performed for this breach.

The lidar data (fig. 22B) show the maximum scour-trench depth at the south end of the IHNC-south breach. Measurements made at $10-\mathrm{m}$ intervals over a $110-\mathrm{m}$ length of intact floodwall at the south end of the breach indicate an increase in scour from 1.1-m depth over the majority of this length from $110-\mathrm{m}$ to $20-\mathrm{m}$ distance from the breach, to $1.6-\mathrm{m}$ depth within $20 \mathrm{~m}$ of the breach. Although not conclusive for determining the failure mode of the breach, these data do indicate that scourtrench depths were higher near to the breach.

\section{Conclusions}

The datasets presented herein portray the scope of available data coverage of the major failed and near-failed sections of the New Orleans levee system following Hurricane Katrina. Data were collected at eight sites, including the 17th Street Canal breach, the north London Avenue Canal breach, and the IHNC breaches in the Lower 9th Ward of New Orleans, several weeks immediately following the dewatering of the city. The electronic data available through this report series can be used to virtually "revisit" the levee failures for such purposes as geometric quantification or morphologic investigation.

Because of the nature of the collection and processing methodologies, care must be taken when using the datasets for measurement purposes. Georeferenced point accuracies vary depending on the type of measurement being made - whether within a single point cloud $(2.5 \mathrm{~cm})$, within two adjacent point clouds (between 7.7 and $16.4 \mathrm{~cm}$ ), or between any point cloud and georeferenced coordinates from an outside dataset (between 10.9 and $164.3 \mathrm{~cm}$ ). The datasets provide unprecedented detail on the failure modes of the levees and form a permanent archive of the failed condition of the major levee breaches that led to the flooding of New Orleans. In view of concerns regarding actual floodwall elevations in relation to supposedly fixed survey-control benchmarks, the USGS datasets are also useful for measuring actual floodwall elevations 

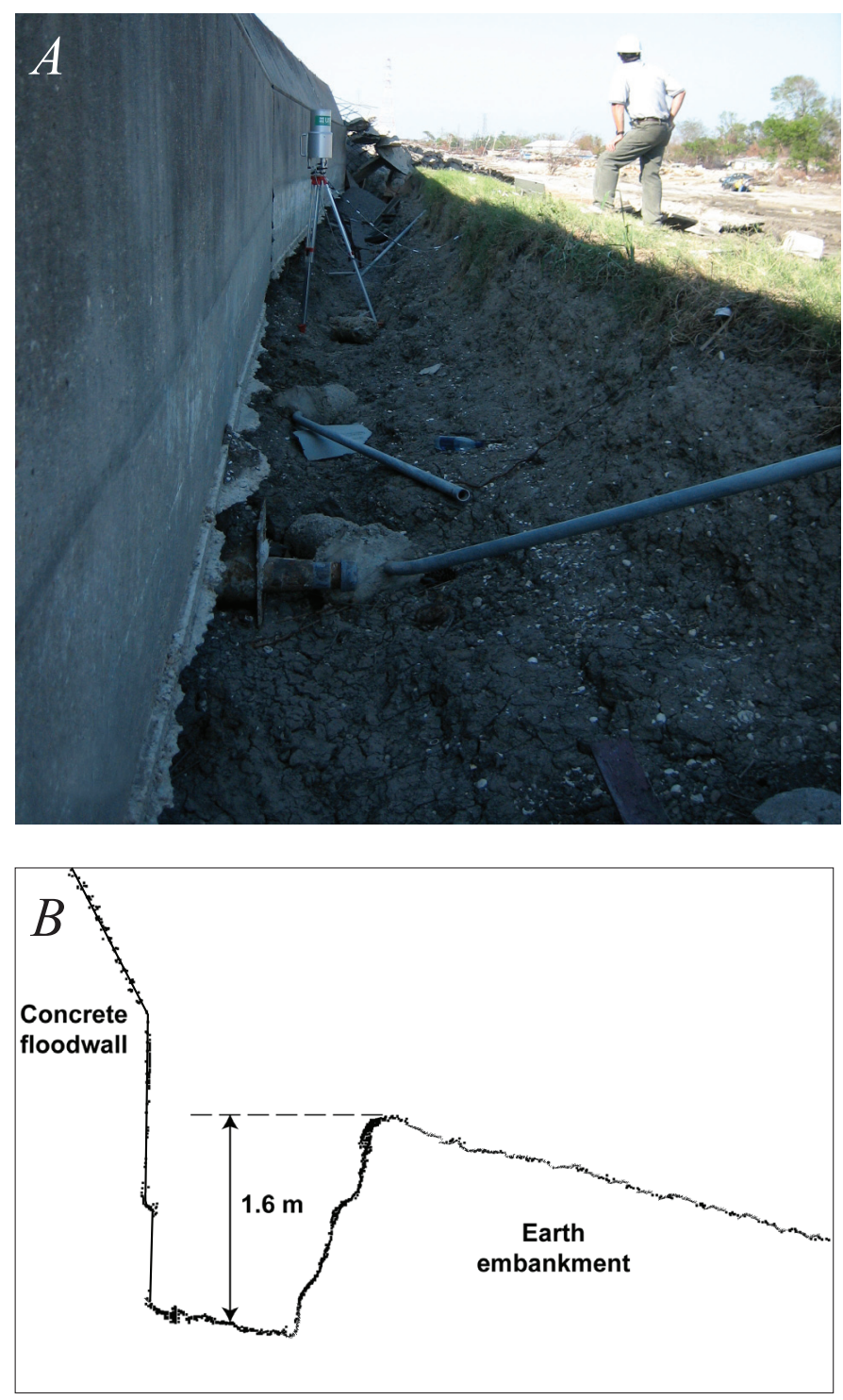

Figure 22. $A$, Scour trench at the south end of Inner Harbor Navigational Canal (IHNC)-East, south breach, looking north. $B$, Measurement of maximum scour-trench dimensions in the point cloud data near the south end of the south breach. The height of the remaining earth embankment is assumed to represent the typical soil height before scour began.

relative to a precise vertical datum (NAVD88). Examples of specific applications of the utility of the data have been presented to provide information on how the datasets may be utilized in ongoing and future investigations of the performance of the levee systems.

\section{Acknowledgments}

Funding for this research was provided by the National Science Foundation and the U.S. Geological Survey, Coastal and Marine Geology Program. We thank Professor Roy Dokka and J. Anthony Cavell of Louisiana State University for their assistance with locating and utilizing the high-accuracy survey benchmark network during the GPS data collection effort. Reviews of this report by Peter Dartnell and John Spritzer of the U.S. Geological Survey are gratefully acknowledged.

\section{References}

Bellian, J.A., Kerans, C., and Jennette, D.C., 2005, Digital outcrop models - applications of terrestrial scanning lidar technology in stratigraphic modeling: Journal of Sedimentary Research, v. 75, no. 2, p. 166-176.

Boehler, W., Vicent, M.B., and Marbs, A., 2003, Investigating laser scanner accuracy: Presented at the XIX International Committee for Documentation of Cultural Heritage (CIPA) Symposium, Antalya, Turkey, 2003, 9 p. [http://cipa.icomos. org/fileadmin/papers/antalya/189.pdf, accessed February 23, 2009].

Collins, B.D., and Sitar, N., 2002, Monitoring of coastal bluffs using 3-D laser scanning and conventional mapping [abs.]: Eos, American Geophysical Union Transactions, v. 83, Fall meeting supplement, abs. H12D-0952.

Collins, B.D., and Sitar, N., 2008, Processes of coastal bluff erosion in weakly lithified sands, Pacifica, California, USA: Geomorphology, v. 97, p. 483-501.

Collins, B.D., Kayen, R., Reiss, T., and Sitar, N., 2007, Terrestrial LIDAR investigation of the December 2003 and January 2007 activations of the Northridge Bluff Landslide, Daly City, California: U.S. Geological Survey Open-File Report 2007-1079, 37 p. [http://pubs.usgs.gov/ of/2007/1079/].

Doneus, M., and Neubauer, W., 2005, Laser scanners for 3D documentation of stratigraphic excavations, in Baltsavias, E., Gruen, A., Van Gool, L., and Pateraki, M., (eds.), Recording, modeling and visualization of cultural heritage: Taylor \& Francis, p. 193-203.

ILIT, 2005, Preliminary report on the performance of the New Orleans levee systems in Hurricane Katrina on August 29, 2005, [Independent Levee Investigation Team (ILIT): Seed, R.B., Nicholson, P.G., Dalrymple, R.A., Battjes, J.A., Bea, R.G. Boutwell, G.P., Bray, J.D., Collins, B.D. Harder, L.F., Headland, J.R., Inamine, M.S., Kayen, R.E., Kuhr, R.A., Pestana, J.M., Silva-Tulla, F., Storesund, R., Tanaka, S., Wartman, J., Wolff, T.F., Wooten R.L., and Zimmie, T.F.]: Berkeley, University of California Center for Information Technology Research in the Interest of Society, submitted to the U.S. Senate, Committee on Homeland Security and Government Affairs, November 2, 2005, 129 p., [http:// www.ce.berkeley.edu/ new_orleans/report/PRELIM.pdf, accessed February 1, 2008]. 
ILIT, 2006, Investigation of the performance of the New Orleans levee systems in Hurricane Katrina on August 29, 2005, [Independent Levee Investigation Team (ILIT): Seed, R.B., Bea, Abdelmalak, R.I., Athanasopoulos, A.G., Boutwell, G.P., Bray, J.D., Briaud, J.-L., Cheung, C., Cobos-Roa, D., Cohen-Waeber, J., Collins, B.D., Ehrensing, L, Farber, D., Hanemann, M., Harder, L.F., Inkabi, K.S., Kammerer, A.M., Daradeniz, D., Kayen, R.E., Moss, R.E.S., Nicks, J., Nimmala, S., Pestana, J.M., Porter, J., Rhee, K., Riemer, M.F., Roberts, K., Rogers, J.D., Storesund, R., Govindasamy, A.V., Vera-Grunauer, X., Wartman, J.E., Watkins, C.M., Wenk, Jr., E., and Yim, S.C.]: Berkeley, University of California Center for Information Technology Research in the Interest of Society, v. 1, 690 p., and v. 2, 517 p. [http://www.ce.berkeley.edu/ new orleans/, accessed February 1, 2008].

IPET, 2007, Performance evaluation of the New Orleans and southeast Louisiana Hurricane protection system: Final Report of the Interagency Performance Evaluation Task Force, v. V, The Performance-levees and floodwalls, June 2007 [https://ipet.wes.army.mil/].

I-SiTE, 2008, 3D Laser Scanning Software: [http://www. isite3d.com, accessed February 1, 2008].

Kayen, R., Collins, B.D., Bawden, G., and Pak, R., 2006. Earthquake ground deformation analysis using scanning laser LIDAR technology: Proceedings of the 100th Anniversary Earthquake Conference, EERI, San Francisco, California, April 18-22, 2006.

Labourdette, R,. and Jones, R.R., 2007, Characterization of fluvial architectural elements using a three-dimensional outcrop data set; Escanilla braided system, south-central Pyrenees, Spain: Geosphere, v. 3, no. 6, p. 422-434.

Nagihara, S., Mulligan, K.R., and Xiong, W., 2004, Use of a three-dimensional laser scanner to digitally capture the topography of sand dunes in high spatial resolution: Earth Surface Processes and Landforms, v. 29, no.3, p. 391-398.

Riegl, 2008, Terrestrial scanning laser systems: [http://www. rieglusa.com, accessed February 1, 2008].
Seed, R.B., Bea, R.G., Abdelmalak, R.I., AthanasopoulosZekkos, A., Boutwell, G.P., Briaud, J.-L., Cheung, C., Cobos-Roa, D., Ehrensing, L., Govindasamy, A.V., Harder, Jr., L.F., Inkabi, K.S., Nicks, J., Pestana, J.M., Porter, J., Rhee, K., Riemer, M.F., Rogers, J.D., Storesund, R., VeraGrunauer, X., and Wartman, J., 2008a, New Orleans and Hurricane Katrina, I; introduction, overview, and the east flank: Journal of Geotechnical and Geoenvironmental Engineering, v. 134, no. 5, p. 701-717.

Seed, R. B., Bea, R. G., Athanasopoulos-Zekkos, A., Boutwell, G.P., Bray, J. D., Cheung, C., Cobos-Roa, D., Ehrensing, L., Harder, Jr. L. F., Pestana, J.M., Riemer, M.F., Rogers, J.D., Storesund, R., Vera-Grunauer, X., and Wartman, J., 2008b, New Orleans and Hurricane Katrina, II; the central region and the lower ninth ward: Journal of Geotechnical and Geoenvironmental Engineering, v. 134, no. 5, p. 718-739.

Seed, R.B., Bea, R.G., Athanasopoulos-Zekkos, A., Boutwell, G.P., Bray, J.D., Cheung, C., Cobos-Roa, D., Harder, Jr. L. F., Moss, R.E.S., Pestana, J.M., Riemer, M.F., Rogers, J.D., Storesund, R., Vera-Grunauer, X., and Wartman, J., 2008c, New Orleans and Hurricane Katrina, III; the 17th Street drainage canal: Journal of Geotechnical and Geoenvironmental Engineering, v. 134, no. 5, p. 740-761.

Seed, R.B., Bea, R.G., Athanasopoulos-Zekkos, A., Boutwell, G.P., Bray, J.D., Cheung, C., Cobos-Roa, D., Cohen-Waeber, J., Collins, B. D., Harder, Jr. L.F., Kayen, R.E., Pestana, J.M., Riemer, M.F., Rogers, J.D., Storesund, R., Vera-Grunauer, X., and Wartman, J., 2008d, New Orleans and Hurricane Katrina, IV; the Orleans east bank (metro) protected basin: Journal of Geotechnical and Geoenvironmental Engineering, v. 134, no. 5, p. 762-779.

Shinkle, K., and Dokka, R.K., 2004, Rates of vertical displacement at benchmarks in the lower Mississippi Valley and the northern Gulf Coast: National Oceanic and Atmospheric Administration Technical Report 50, 135 p.

Wawrzyniec, T.F., McFadden, L.D., Ellwein, A., Meyer, G., Scuderi, L., McAuliffe, J., and Fawcett, P., 2007, Chronotopographic analysis directly from point-cloud data - a method for detecting small, seasonal hillslope change, Black Mesa Escarpment, NE Arizona: Geosphere, v. 3, p. 550-567. 
Produced in the Western Region, Menlo Park, California Manuscript approved for publication, September 9, 2009 Edited by Peter Stauffer

Layout by David R. Jones 
